\title{
Masinès suvenyrinių ženklelių gamybos fenomenas Sovietų Lietuvoje
}

\section{Rasa Dargužaitė}

Lietuvos kultūros tyrimų institutas Saltoniškių g. 58, LT-08015 Vilnius rasadarguzaite@gmail.com

— Straipsnyje aptariami Lietuvoje sovietiniu laikotarpiu, 19451990 m., masiškai gaminti ženkleliai, jų plitimo priežastys, funkcija ir dizaino ypatumai. Publikacijos tikslas - atskleisti kol kas menkai tyrinètą fenomeną, aptarti ženklelių propagandinị vaidmenị ir su juo susijusias menines savybes. Keliamas klausimas, kaip atsirado ženklelio formos suvenyrai ir kas darè įtaką jų masinei gamybai. Nagrinëjant pagrindinį tyrimo objektą, trumpai apžvelgiami lituanistiniai ženklai ir ženkleliai, plitę Lietuvoje iki sovietmečio. Paliečiamas suvenyro, kuriam sovietiniu laikotarpiu buvo skiriama ypač daug dèmesio, klausimas.

Reikšminiai žodžiai: dizainas, suvenyras, sovietinè propaganda, ženkleliai. 
Žodynuose ir enciklopedijose ženklelis apibūdinamas kaip nedidelis metalinis, plastikinis ar kitos medžiagos daiktas su piešiniu ir (arba) tekstu, skirtas liudyti paramą, pasiekimus, priklausomybę organizacijai, pažymèti ịvykị (proginis), vietą, reklaminis, propagandinis. Ženkleliai, skirti propagandai, plačiai naudoti autoritarinėse bei totalitarinèse valstybėse ir per karus ${ }^{1}$. Ženklelio kūrimo principas artimas emblemai - juos sieja komunikacijos aspektas - žinios perteikimas per vaizdą. Kitaip tariant, ,ženklai suvokiami vizualiai $[. . .]^{\text {“2 }}$. Nors ženkleliai - masinis dirbinys, tačiau verta i juos pažvelgti kaip į dailininko suprojektuotą nedidelị kūrinį, kuriame turi derèti simbolika, perteikiama žinia ir estetinis apipavidalinimas.

Sovietmečiu skatinta ir propaguota masinè suvenyrų, taigi ir ženklelių, gamyba. Iš pirmo žvilgsnio šie nedideli dirbiniai atrodo marginalūs ir neverti dẻmesio. Tačiau peržvelgus jų asortimentą, išryškẻja aspektai, kuriais remiantis galima analizuoti ne vieną kontekstą: pirma - ženklelio ikonografija leidžia nagrinèti, kaip formuotas renginio, įstaigos, miesto ir panašiai įvaizdis; antra - analizuojant ženklelius, galima rekonstruoti sovietmečio žmogaus darbo, laisvalaikio pramogų pasiūlą ir aktualijas - socialini gyvenimą; trečia - sporto, turizmo, kultūrinių renginių (festivalių, parodų) ženkleliai padeda nusakyti vykusių renginių istoriją; ketvirta - ženkleliai, skirti apdovanojimams (varžybų nugalètojams, darbo spartuoliams ir pan.), išryškina vieną iš sovietinès ideologijos diegimo strategijų.

JAV dizaino kritikas Stevenas Helleris knygoje Iron Fists: Branding the 20th Century Totalitarian State (Geležiniai kumščiai: XX amžiaus totalitarinès valstybès ženklinimas) ${ }^{3}$ nagrinėja keturių $\mathrm{XX}$ a. totalitariniu režimų - nacistinès Vokietijos, fašistinès Italijos, SSRS ir komunistinės Kinijos - propagandinę dailę, kuri pasitelkta ịtvirtinti savo ideologiją visuomenèje. Knygoje daugiausia dèmesio skirta propagandinei grafikai; autorius išryškina, kokia vaizdinè retorika naudota logotipuose, plakatuose, reklamose, vèliavose ir net vaikų knygų iliustracijose. Leidinyje taip pat aptartas ir ženkleliu gamybos - XX a. 7 deš. masiškai tiražuotų ženklelių su Mao atvaizdu Kinijoje ${ }^{4}$ - atvejis.

1 „Ženklelis“, https://www.vle.lt/straipsnis/zenklelis/; „Badge“, https://www. oxfordlearnersdictionaries.com/definition/english/badge? $q=$ badge.

2 Audrius Klimas, Lietuvos prekiu ženklai: istorija, funkcija, klasifikacija (Vilnius: Vilniaus dailès akademijos leidykla, 2009), 7.

3 Steven Heller, Iron Fists: Branding the 20th Century Totalitarian State (New York: Phaidon Press, 2010).

4 Ibid., 181-182. 
Knygos Badges \& Insignia of the Third Reich 1933-1945 (Trečiojo Reicho ženkleliai ir insignijos 1933-1945) autoriaus Braino Leigho Daviso ${ }^{5}$ surinkta medžiaga parodo masiškai gamintų ir naudotų nacistinès Vokietijos ženkleliu įvairovę ir paplitimą. Pasak jo, ženklelių ir insignijų dėvėjimas ypač plito Antrojo pasaulinio karo metu. Nacistinės Vokietijos ženkleliai ir insignijos beveik visada buvo kokybiški, gero dizaino ir gamybos. Juos kūrè specialūs karo dailininkai ir dizaineriai, vienas žymiausių - Egonas Jantke $e^{6}$. Šis leidinys labai gerai iliustruoja, kaip per nedidelio formato dèvimus ženklelius ir emblemas skleista ir tvirtinta nacistinè ideologija visuomeneje. Tad totalitariniai režimai propagandos sklaidai rinkosi nuo gigantišku monumentų iki smulkių masiškai gaminamų ženklelių.

\section{Ženklelių tyrimai ir kolekcijos Lietuvoje}

Sovietinių suvenyrinių ženklelių tematika labai menkai tyrinèta. Daugiausia publikacijų, apžvalgų ir tyrimų yra tarpukario ženklelių tema. Apie juos rašè muziejininkẻ Rūta Verkelienè, aptardama Nacionalinio M. K. Čiurlionio dailès muziejaus (toliau - NČDM) faleristikos rinkinį, kuriame daugiau dèmesio skirta tarpukario ir JAV lietuvių bendruomeniu gamintiems ženkleliams ${ }^{7}$. Muziejininkas Ignas Narbutas konferencijos „Šiuolaikinès gairès ir aktualijos numizmatikoje, faleristikoje ir sfragistikoje“" pranešime pateikė XIX a. pabaigos - XX a. pradžios JAV lietuvių faleristikoje naudotą heraldiką, tuo pačiu supažindino su ženkleliu asortimentu ir ju paskirtimi, vizualine raiška. Išsiskiria muziejininko Eduardo Remeco išsamūs ir vertingi straipsniai, skirti tarpukariu kurtiems ženkleliams ${ }^{9}$. Tyrinètojas aprašo, kokios įmonès juos gamino, kokia buvo kaina, kur skelbta ir kokios buvo ženklelio projekto sukūrimo sąlygos, kam jie buvo skirti ir

5 Brian Leigh Davis, Badges \& Insignia of the Third Reich 1933-1945 (Poole, Dorset: Blandford Press, 1984).

5 Ibid., 7.

7 Rūta Verkelienė, „Retesni mažosios faleristikos eksponatai“, in Mažieji Lietuvos istorijos paminklai Nacionalinio M. K. Čiurlionio dailes muziejaus Numizmatikos skyriaus rinkiniuose (Kaunas: Nacionalinis M. K. Čiurlionio dailès muziejus, 1999), 119-131.

8 Ignas Narbutas, „XIX a. pabaigos - XX a. pradžios JAV lietuvių faleristikoje naudojamos heraldikos kilmë“, in Šiuolaikinès gairès ir aktualijos numizmatikoje, faleristikoje ir sfragistikoje (Trakai: Trakų istorijos muziejus, 2006), 56-58.

9 Eduardas Remecas, „Katalikiški ženkleliai tarpukario Lietuvoje: jų priklausomybė, datavimas, platinimas ir tiražavimas“, Lietuvos katalikų mokslo metraštis 37 (2013): 207-226; Euduardas Remecas, „Lietuvos sukarintų organizacijų ženklai ir ženkleliai (1918-1940): istorija ir datavimas“, Karo archyvas 30 (2015): 343-377; Euduardas Remecas, „Lietuvos skautų organizacijos ženkleliai 1918-1940 m.“, Lietuvos kataliku mokslo metraštis 42 (2019): 183-215. 
kokią atliko funkciją, patikslino arba atributavo kai kurių dailininkus. Konferencijose būta ir daugiau pranešimu faleristikos tema ${ }^{10}$, tačiau jie dažnu atveju skirti tarpukario ženklelių tyrimams ${ }^{11}$.

Menotyrininkė Skirmantė Smilingytė-Žeimienė straipsnyje „Šiek tiek apie mažiausius Lietuvos istorijos paminklus“12 pateikè kai kurių tarpukario sukurtų ženklelių autorius ir pabrèžè, kad XX a. pirmos pusès Lietuvos ženkleliai dailètyrininkų netyrinèti, tad ir daugelio jų dailininkai vis dar nėra žinomi ${ }^{13}$. Pažymėtina, kad ir sovietiniu laikotarpiu kurtų ženklelių autoriai taip pat dažniausiai yra nežinomi. Vilniaus dailès akademijos bibliotekoje saugomi Felikso Daukanto ženklelių eskizai14, dailininko šeimos archyve - ženklelių pavyzdžiai ${ }^{15}$. Išlikę ir Vytauto Zarankos kurtų ženklelių projektai ${ }^{16}$. Straipsnio autorei pavyko surasti archyvinę medžiagą - dali išlikusių „Dailès“ kombinatų ${ }^{17}$, „Metalisto“, „Minijos“, „Ūlos“ ir kitų meno įmonių dirbinių techninius pasus ${ }^{18}$, kuriuose išsamiai aprašyti gaminiai (nurodytas autorius, dirbinio pavadinimas, tiražas, honoraras) su nuotraukomis. Šie dokumentai svarbūs ne tik tyrinėjant ženklelių tematiką, bet ir padès atributuoti daugiau „Dailès“ kombinatų ir kitų meno ịmonių gamintų dirbinių dailininkus ir gamintojus.

Apie sovietinius ženklelius yra rašyta muziejininko Gintaro Džiovėno. Jis tiek straipsnyje, tiek konferencijos pranešime aptarẻ turistinius sovietiniu laikotarpiu gamintus ženklelius ${ }^{19}$. Nors Lietuvos nacionalinio

10 Asta Jakštienė, Rūta Kuodytè ir Rita Povilovska, „Šiuolaikinių lituanistinių faleristikos eksponatų saugojimo problema“, in Lietuvos muzieju rinkiniai: XI mokslinè konferencija Lituanistika muziejuose (Vilnius: Lietuvos muziejų asociacija, 2009), 97-100.

112013 m. vykusioje tarptautinėje konferencijoje Medininkų pilyje „Numizmatikos tyrimai: rinkiniai ir nauji ịsigijimai“ numizmato E. Remeco pranešimas buvo skirtas tarpukario ženkleliams: Eduardas Remecas, „Numizmatikos tyrimai: rinkiniai ir nauji issigijimai“, in Numizmatika, 13/17 t. (Vilnius: Lietuvos nacionalinis muziejus, 2017), 225; Arvydas Jakštas, „Faleristikos kolekcijos Lietuvos sporto muziejuje (1918-1940)“, in Lietuvos muzieju rinkiniai, XI mokslinė konferencija Lituanistika muziejuose (Vilnius: Lietuvos muziejų asociacija, 2009), 94-96.

12 Skirmantė Smilingytė-Žeimienė, „Šiek tiek apie mažiausius Lietuvos istorijos paminklus“, Menotyra 2 (19) (2000): 39-41.

13 Ibid., 39.

14 Vilniaus dailès akademijos bibliotekos rankraščiu skyrius. F. 3. Felikso Daukanto archyvas.

15 Felikso Daukanto (1915-1995) archyvas, šeimos nuosavybè.

16 Vytauto Zarankos (1933-2021) archyvas, šeimos nuosavybè.

17 „Dailès“ kombinatų dirbinių techniniai pasai dingo po 1990 m., irstant kombinatų sistemai.

18 Techniniai pasai saugomi Asociacijos LATGA archyve, Jono Basanavičiaus g. 4B, Vilnius. Iki 1990 m. veikè Sajunginė autorių teisių agentūra (Всесоюзное агентство по авторским правам (BAАП), kuriai buvo pateikiami taikomosios dekoratyvinès dailès tiražuojamų dirbinių techniniai pasai.

19 Gintaras Džiovėnas, „Lietuvos turizmo istorija ženkleliuose ir medaliuose“, Lietuvos muziejai 2 (2003), http://www.museums.lt/Zurnalas/Dziovenas.htm; Gintaras Džiovėnas, „Turistiniai ženkleliai iki 1990 m. ir jų rinkimas“, in Lietuvos muzieju rinkiniai (Vilnius: Etnomedijos spauda, 1999), 58-60. 
muziejaus (toliau - LNM) leidžiamame Numizmatikos ${ }^{20}$ metraštyje sovietinių ženklelių tematika tyrimų nėra, tačiau čia galima rasti 2000-2006 m. sudarytas lenteles apie muziejuose saugomus numizmatikos rinkinius, kuriuose išskirtos ir faleristikos kolekcijos. Tai leidžia sužinoti, kuriuose muziejuose saugomi faleristikos pavyzdžiai, tarp jų ir ženkleliai. Metraščių parodų apžvalgose yra informacijos apie surengtas faleristikos parodas, kuriose dažniausiai eksponuoti privačių kolekcijų ženklelių rinkiniai. Jos rengtos bibliotekose, mokslo įstaigose, kartais galerijose ${ }^{21}$. Pažymėtina, kad Traku istorijos muziejuje $2013 \mathrm{~m}$. parodoje Trakai numizmatikoje kartu su monetomis, banknotais, medaliais, apdovanojimais eksponuoti ir ženkleliai; tuo pačiu pavadinimu buvo parengtas ir leidinys ${ }^{22}$. Kadangi parodos koncepcija buvo parodyti Trakų miesto ir pilių ịamžinimą numizmatikoje ${ }^{23}$, eksponuoti ženkleliai taip pat buvo susiję tik su miesto ir jame vykusių renginių tematika, čia daugiausia buvo sovietinio laikotarpio pavyzdžių (suvenyriniai miesto, sporto varžybų ženkleliai).

Galima sakyti, kad vis dèlto daugiausia dèmesio ženkleliams skiria kolekcininkai. Kai kurie jų arba organizacijos renka juos pagal temas, pavyzdžiui: sporto (Lietuvos olimpinė kolekcininkų asociacija vienija sporto kolekcininkus) arba tik vienos sporto šakos (pvz., Lietuvos orientavimosi sporto organizacija), miestų arba tik vieno miesto ir su juo susijusia atributika (kolekcininkų Birutès Railienès ir Dariaus Railos rinkinį sudaro ženkleliai, susiję su Vilniaus miestu), miesto herbų, nusipelniusių žmonių, įmonių, gamyklų, proginius. Kolekcininkas Bronius Žaliauskas sudarè ir parengè spaudai turistinių ženklelių katalogą ${ }^{24} \mathrm{su}$ aprašymais (nurodyta išleidimo vieta ir metai, gamintojas, kartais autorius, tiražas) ir su savo originaliais piešiniais. Deja, katalogas nebuvo išleistas.

20 Metraštis Numizmatika leidžiamas nuo 2000 m., iki 2017 m. išleisti 7 numeriai.

$212010 \mathrm{~m}$. Vilniaus Gedimino technikos universiteto bibliotekoje surengta paroda Krepšinis ženkliukuose, daugiau žr. Rūta Kuodytè, „Krepšinis ženkliukuose“, in Numizmatika, 9 / 12 t. (Vilnius: Lietuvos nacionalinis muziejus, 2012), 364-365. 2014 m. Šiaulių miesto savivaldybės viešojoje bibliotekoje veikè paroda Šiauliai ženkliukuose, 2016 m. surengtos parodos: Šiauliuose „Laiptų“ galerijoje Su krepšinio kamuoliu per pasauli, Molètų viešojoje bibliotekoje Iš mūsu kolekcijų: ženkliukai, Lietuvos edukologijos universitete Vilniuje Rusijos istorija ženkleliuose, Vilniuje Medicinos bibliotekoje Lietuvos medicina ženkleliuose. Daugiau žr. Numizmatika, 13 / 17 t. (Vilnius: Lietuvos nacionalinis muziejus, 2017), 208, 217-219.

22 Virgilijus Poviliūnas, Irena Senulienè ir Oleg Ševeliov, sud., Trakai numizmatikoje (Trakai: Trakų istorijos muziejus, 2013).

23 Ibid., 3.

24 Bronius Žaliauskas, sud., Lietuvos TSR ženkliuku katalogas: Turizmas [maketas parengtas spaudai su originaliais B. Žaliausko piešiniais], Vilnius, 1989, mašinraštis. Lietuvos nacionalinio muziejaus archyvas, F. NM, Apr. m., b. 278. 
Vienas išsamiausių leidinių, skirtų faleristikai, publikuotas 1993 m., sudarytas kolekcininko Algimanto Astiko ${ }^{25}$. Jame išsamiai aprašyta (pateikta informacija apie organizaciją, ženklelio išmatavimai, medžiaga, vaizdo ir priesago aprašas, kai kur nurodyta konkurso data, projekto autorius, gamintojas, kaina) 1918-1940 m. daugiau kaip 400 pagamintų ženkleliu su grafiniu vaizdu. Svarbus ikonografinis šaltinis - faleristikos kolekcininku B. ir D. Railų sudarytas albumas Vilnius ženkleliuose $e^{26}$, kuriame publikuoti 538 ženkleliai su pakankamai išsamia metrika, taip pat ịvardyti gamintojai. Su miestais susijusių ženklelių rinkinių albumų išleista ir daugiau: kolekcininko Petro Kaminsko sudarytas katalogas Šiauliai faleristikoje 1879-2016 $6^{27}$, Algimanto Kšivicko - Jonava faleristikoje ${ }^{28}$. Verti dèmesio katalogai, kuriuose surinkti ženkleliai, skirti apdovanojimams ${ }^{29}$, mokslo istaigoms ${ }^{30}$. Kolekcininkų sudaryti leidiniai ir rankraščiai pasitarnauja ir muziejininkams ${ }^{31}$, nepaisant kai kurių netikslumų, jie vis dar lieka aktualūs, nagrinëjant ženklelius. Kita vertus, ženkleliai muziejininkų ir menotyrininkų dėmesio nesulaukè greičiausiai dèl masinès gamybos. Tai nebuvo reti, unikalūs eksponatai, o kaip i̇ dizaino objektus nebuvo atsižvelgta.

Kaip minèta anksčiau, apie muziejuose saugomas faleristikos kolekcijas iš dalies galima sužinoti iš Numizmatikos metraščiuose sudarytu lenteliụ. Panašu, kad ne visi muziejai pateike duomenis apie savo turimus eksponatus, be to, informacija jau yra pakitusi, tačiau iš esamų duomenų galima susidaryti bendrą vaizdą. Didžiausios faleristikos kolekcijos saugomos LNM, NČDM ir Trakų istorijos muziejuje. Kai kuriuose muziejuose ženkleliai renkami pasirinkta tema ${ }^{32}$, pavyzdžiui, susiję su miestu (jo simbolika,

25 Algimantas Astikas, Lietuvos ordinai, medaliai ir ženkleliai 1918-1940 (Vilnius: Mintis, 1993).

26 Birutė Railienè ir Darius Raila, sud., Vilnius ženkleliuose (Vilnius: Lietuvos mokslụ akademijos Vrublevskių biblioteka, 2005).

27 Petras Kaminskas, Šiauliai faleristikoje 1879-2016 (Šiauliai, 2016); Šiauliai faleristikoje 1924-2020 (Šiauliai: spaustuvè „Titnagas“, 2020).

28 Algimantas Kšivickas, Jonava faleristikoje (Vilnius: Diemedžio leidykla, 2018).

29 Andrius Baronas, Lietuvišku garbès ženklų katalogas (Kaunas: V. Staniulio knygynas, 2018).

30 Skirmantas Andriušis ir Raimundas Petrikas, Lietuvos mokslo instituciju absolventu ženklai (1918-1989) (Kaunas: Eurispauda, 2019).

31 Rūta Kuodytė, „Algimanto Astiko kolekcija ir jos reikšmė Lietuvos nacionalinio muziejaus faleristikos ir filofaleristikos rinkinių formavimui“, in Lietuvos muzieju rinkiniai: XIII mokslinė konferencija Lietuvos muziejininkystè: raida ir asmenybès (Vilnius: Lietuvos muziejų asociacija, 2010), 93-97.

32 Pavyzdžiui, Jūrų muziejaus Klaipėdoje sukauptos kolekcijos rinkinyje vyrauja jūrinès tematikos ženkleliai. 
paminklais, objektais, istoriniais įvykiais, minejjimais ir pan.), kuriame yra muziejus. Deja, muziejų aprašuose dažnai nenurodytas nei gamintojas, nei projekto autorius, kartais ir sukūrimo vieta nurodyta labai apibendrintai (sovietmečio laikotarpio dažniausiai pasirenkama tiesiog įrašyti SSRS).

LNM numizmatikos rinkinyje saugomas vienas didžiausių faleristikos rinkinių, kurị sudaro senieji ženklai, tarpukario ženkleliai ir ypač didelis sovietinio laikotarpio ženklelių rinkinys. Tad verta skirti šiek tiek daugiau dèmesio kone didžiausiai Lietuvoje faleristikos kolekcijai. Rinkinyje saugomi XIX a. - XXI a. pradžios suvenyriniai, propagandiniai, jubiliejiniai ženkleliai, organizacijų, identifikavimo, skiriamieji ir kitokio pobūdžio ženklai. Didžiają jo dali sudaro sovietiniai XX a. antros pusès propagandiniai ir suvenyriniai ženkleliai. Dalis eksponatų - tai buvusių Revoliucijos muziejaus (veikè 1948-1991) ir Ateizmo muziejaus (veikè 1961-1992) Vilniuje ženklų ir ženklelių rinkiniai. $1984 \mathrm{~m}$. muziejus įsigijo turistinių ženklelių rinkinị iš kolekcininko Antano Rudzevičiaus, 1988 m. - iš Algimanto Urbono ${ }^{33}$, 1994 m. - kolekcininko Algimanto Astiko (1929-1990) surinktą tarpukario Lietuvos ženklų ir ženklelių kolekciją. 2018 m. LNM padovanota kolekcininko Rimvydo Racėno kolekcija. Čia saugomos asmeninės signataro Romualdo Ozolo, visuomenès veikèjos Gražinos Ručytès-Landsbergienės surinktos ženklelių kolekcijos ${ }^{34}$.

NČDM nemažą faleristikos rinkinio dalị sudaro numizmato Aleksandro Mykolo Račkaus (1893-1965) sukaupta ir dovanota muziejui JAV lietuvių draugijų ir organizacijų ženklų ir ženklelių kolekcija ${ }^{35}$. Taip pat yra propagandinių, proginių, sporto klubų bei įvairių organizacijų ženklelių ${ }^{36}$.

Nepaisant muziejuose saugomų sovietinių ženklelių gausos, jie kol kas mažiau tirti. Kaip minèta anksčiau, daugiau dèmesio ženklelių rinkiniams skiria kolekcininkai, rengdami parodas, leisdami katalogus, tuo pačiu siekdami susisteminti savo turimas kolekcijas.

33 Džiovènas, „Lietuvos turizmo istorija ženkleliuose ir medaliuose“.

34 Informaciją pateikė LNM muziejininkè Rūta Kuodytė, 202103 15, autorès asmeninis archyvas.

35 Narbutas, „XIX a. pabaigos - XX a. pradžios JAV lietuvių faleristikoje naudojamos heraldikos kilmé“, 56 .

36 Verkelienè, „Retesni mažosios faleristikos eksponatai“, 119. 


\section{Suvenyrų aktualumas sovietmečiu}

Sovietiniu laikotarpiu ne tik ženkleliu gamyba, bet ir visa suvenyrinė gamyba buvo skatinta ir propaguota. Tai atsispindi ir archyviniuose dokumentuose (Dailès fondo posėdžiuose buvo dažnai aptariama tema), ir išleistuose žinynuose bei atskirose apžvalgose ${ }^{37}$, meno dirbinių kataloguose, tai patvirtina ir sovietiniu laikotarpiu suvenyrų gamyklu gausa visoje Sovietų Sąjungoje. Latvijoje suvenyrus gamino kombinatas „Māksla“, „Suvenīrs“ir kiti, Estijoje - kombinatas „Ars“, fabrikas „Salvo“ ir kiti; veikè eksperimentinès suvenyrų įmonès ir gamyklos - Uljanovsko bandomųjų eksperimentinių suvenyrų gamykla (Ульяновский опытно-экспериментальныий завод сувениров), Pavlovo suvenyrų gamykla (Павловский завод сувениров), Bandomuјjų ir suvenyriniu gaminių gamykla (Завод опытных и сувенирных изделий) Mytiščiuose, Meninè-eksperimentinė įmonė „Kolskij suvenir“ (Художественноэкспериментальное предприятие «Кольский сувенир») Murmanske ir kitos.

Lietuvoje daugiausia suvenyrinių dirbinių katalogų (apie 50) išleido meno dirbinių susivienijimas „Dovana“"38, kurio produkcija nepasižymejjo itin aukštu meniniu lygiu. Ją sudarè keramikos, dailiosios tekstilès, odos, vytelių, metalo, rago, gintaro dirbiniai. Pagal $1969 \mathrm{~m}$. duomenis, pagrindiniai suvenyru gamintojai buvo susivienijimas „Dovana“, pagaminusi 66 proc., ir „Dailès ${ }^{\text {“39 }}$ kombinatai, pagaminę 20,7 proc. $^{40} .1972$ m. išleistoje analitinėje suvenyrinės gamybos apžvalgoje ${ }^{41}$ publikuotas Lietuvos KP Centro komitete ir Lietuvos SSR Ministrų taryboje svarstytas suvenyrų meninis, tiksliau tariant, propagandinis idèjinis klausimas. Minètos institucijos:

ịpareigojo < ... žymiai pakelti <...> dirbinių idèjinị meninị lygị, nuolat rūpintis jų tematiniu kryptingumu, plačiau taikyti, kuriant suvenyrus, geriausias tarybinio

37 Teminis meno verslu ir suvenyru katalogas (Vilnius: Mintis, 1971); Vaclovas Prekevičius, Gediminas-Leonas Samuolis, Dailès dirbiniu ir suvenyru gamyba ir jos išsivystymo Lietuvos TSR vietinèje pramonèje problemos (Vilnius: Lietuvos mokslinès techninės informacijos ir techninès ekonominès analizès mokslinio tyrimo institutas, 1972).

38 Meno verslų ir suvenyrų gamybinis susivienijimas „Dovana“ (įkurtas 1967) jungė šešias meno įmones: Kauno (ịkurta 1968), Vilniaus (ikurta 1969), „Jiesios“ (Kaune; ikurta 1962), „Minijos“ (Plungèje; ịkurta 1963), „Tulpės“ (Panevėžyje; ịkurta 1966) ir Druskininkų (įkurta 1968). Daugiau žr. Aleksandras Budrikas, „Dovana“, in Tarybu Lietuvos enciklopedija, t. 1 (Vilnius: Vyriausioji enciklopedijų redakcija, 1984), 447.

39 Kaune (nuo 1945), Vilniuje ir Klaipėdoje (abiejuose nuo 1946) veikè trys „Dailès“ kombinatai, kurie turèjo savo skyrius kituose miestuose (Panevėžyje, Šiauliuose, Palangoje ir kitur).

40 Prekevičius ir Samuolis, Dailes dirbiniu ir suvenyru gamyba ir jos išsivystymo Lietuvos TSR vietinèje pramonejje problemos, 7 .

41 Ibid. 
vaizduojamojo ir taikomojo meno tradicijas, turint galvoje, kad suvenyrai turi tarnauti patriotiniam ir internacionaliniam darbo žmonių auklèjimui, tarybinès liaudies revoliuciniu, kovos ir darbo tradiciju propaganda, daugiau atspindèti darbo žmonių laimėjimus, pasiektus vystant respublikos ekonomiką ir kultūrą. ${ }^{42}$

Nutarime labai aiškiai ivvardijama, kokia privalo būti suvenyro paskirtis - tarnauti patriotiniam (tiksliau propagandiniam) žmonių auklẻjimui. Tokio tipo vadinamieji ,auklėjamojo“ pobūdžio suvenyrai gaminti „,minint“" pergalę kare, V. Lenino gimimo metines, revoliucionieriu portretai ${ }^{43}$, kurti kaip apdovanojimai darbo pirmūnams ir žymūnams, spartuoliams ir panašiai.

Meno įmoniu ,pagrindinis gamybinis uždavinys $<\ldots>$ pakelti gaminių meninę kokybę. < ..> gamyboje tematiniai dekoravimo principai turi būti pagrịsti tarybinès ideologijos ir politinio lavinimo siekimais: tautiniais pagal formą, socialistiniai pagal turini. “" ${ }^{44}$ Pastarasis teiginys sovietmečiu tapo kone paradigma, cituotas beveik visur, kur buvo kalbama apie meną. Pažymètina, kad sovietiniu laikotarpiu suvenyro samprata itin glaudžiai sieta su liaudies meno dirbiniais:

Lietuvos TSR Vietinės pramonès ministerijos meno verslų dirbinių ir suvenyru gamybinis susivienijimas „Dovana“, gamybiniai dailès fondo Vilniaus, Kauno ir Klaipėdos kombinatai „Daile““, Liaudies meno draugija stengiasi atgaivinti, ugdyti ir toliau puoselèti senąsias liaudies meno tradicijas. ${ }^{45}$

Masiškai gaminti vadinamụjų liaudies meistrų tradiciniai, dažnai stilizuoti, medžio (skulptūrèlès, dekoratyvinès verpstės, kaukès, žaislai, žvakidès, skrynios ir pan.), tekstilès (lèlès, aprėdytos tautiniais drabužiais, rankšluosčiai, juostos, staltiesės ir pan.), keramikos (gèrimų servizai, vazelès, skulptūrèlès ir pan.) ir gintaro (papuošalai, suvenyrinès skulptūrèlès ir

42 „Dèl priemonių idėjiniam meniniam suvenyrų lygiui toliau kelti. Lietuvos KP Centro Komiteto ir Lietuvos TSR Ministru Tarybos nutarimas. 1974 m. sausio 14 d.“, in Ideologinio darbo klausimai (Vilnius: Mintis, 1975), 112.

43 Rasa Dargužaitè-Riškienè, „Vilniaus „Dailès“ kombinatas 1945-1990 m.: organizaciniai veiklos aspektai“ (magistro baigiamasis darbas, Vilniaus dailès akademija, 2020), 46-47.

44 Kombinato „Daile““ direktoriui, 1948 m. vasario [9], vyriausiasis direktorius K. Šaltenis. (Nuorašas: LTSR Tarybinių Dailininkų Sajungai ir LTSR Tarybinių Dailininkų Sajungai Kauno Skyriui), Lietuvos literatūros ir meno archyvas (toliau - LLMA), F. 350, ap. 1, b. 10, (72 l.), 11.

45 Teminis meno verslu ir suvenyru katalogas, 3. 
pan.) dirbiniai. Čia verta paminèti istorikès Nerijos Putinaitès tautinès industrijos ${ }^{46}$ apibūdinimą, kurị ir iliustruoja minètų dirbinių masinė gamyba. Atkreiptinas dèmesys i temini suvenyrų kataloga $a^{47}$, sudarytą kaip praktini , „vadovą“ dailininkams semtis idejų kuriant suvenyrus. Jame suvenyrai klasifikuojami ị tikruosius (kuriuos, pasak leidinio rengejjų, ìvairiais laikotarpiais kūrè amatininkai, liaudies meistrai, dailininkai), suprojektuotus dailininkų-dizainerių-konstruktoriu (skirtus meninės pramonès tiražavimui), ir reklaminius-adaptacinius (skirtus konkrečiai vietovei, objektui, ìvykiui paminèti, informuoti) ${ }^{48}$. Pasak leidinio rengėjų, žinynas sudarytas siekiant plèsti suvenyrų tematiką. Temos suskirstytos ị keturis skyrius: istorinę ir meninę, liaudies meno, tautosakinę ir literatūrinę tematiką. Istorinio pobūdžio suvenyrų temos: vadinamoji „garbinga revoliucinè praeitis“, archeologija, istorija, menas, architektūros paminklai, piliakalniai ir milžinkapiai, dailès ir istorijos paminklai ${ }^{49}$. Vadinamosios revoliucinès praeities skyriuje surašyti komunistiniai veikejai (Zigmas Aleksa-Angarietis, Feliksas Dzeržinskis, Vincas Mickevičius-Kapsukas ir kt.); prie kiekvienos personalijos pateikta trumpa biografija, nuorodos ị šaltinius apie juos, citatos, vizualiai sektini pavyzdžiai (pvz., paminklai) ${ }^{50}$. Formuota suvenyro samprata, „kad jame atsispindi aukštos idẻjinès ir meninès savybès.“51

„Dailès“ kombinatuose suvenyrinè produkcija daugiausia gaminta pagal užsakymus. Užsakovai buvo ir valdžios institucijos (Aukščiausiosios Tarybos Prezidiumas, Kultūros, Vidaus reikalų, Užsienio reikalų, Žemès ūkio ir kt. ministerijos, Respublikos miestų vykdomieji komitetai ir kt.), ir ìvairios visuomeninès įstaigos (muziejai, gamyklos, fabrikai, kolūkiai, valgyklos, restoranai, pašto skyriai, mokyklos, ligoninès, bibliotekos, kultūros rūmai, knygynai, poilsio namai ir kt. $)^{52}$. Tuo tarpu vadinamosiose meno įmonėse daugiausia gaminti liaudies meistrų dirbiniai pardavimui. Galbūt šis aspektas ir lėmè tai, kad susivienijimo „Dovana“ išleista per 50 katalogų, kurie dabar yra svarbi informacinè ir ikonografinè medžiaga, padedanti rekonstruoti sovietiniu laikotarpiu vyravusios meno dirbinių masinès

46 Nerija Putinaitè, Skambantis molis: Dainu šventès ir Justino Marcinkevičiaus trilogija kaip sovietinio lietuviškumo ramsčiai (Vilnius: Naujasis Židinys-Aidai, 2019).

47 Teminis meno verslų ir suvenymų katalogas.

48 Ibid., 3.

49 Ibid., 6.

50 Ibid., 6-9.

51 Ibid., 26.

52 Dargužaitè-Riškienè, „Vilniaus „Dailès“ kombinatas 1945-1990 m.“, 40-42. 
produkcijos pasiūlą ir meninę raišką. Pažymėtina, kad „Dailès“ kombinatuose daugiausia dirbo profesionalūs dailininkai, jų kurta produkcija vertingesnè meniniu aspektu. Tačiau buvo išleisti, manoma, tik penki apibendrinamojo pobūdžio katalogai (bukletai) ${ }^{53}$. Galima daryti prielaidą, kad kombinatams nebuvo poreikio leisti dirbinių katalogus (nors Lietuvos dailès fondo posėdžiuose svarstyti katalogų rengimo klausimai ${ }^{54}$ ), nes jų didžiaja produkcijos dalį sudarè užsakymai.

„Dailès“ kombinatuose suvenyrai gausiai kurti profesionalių dailininkų (ne tik liaudies meistrų) švenčių, festivalių, parodų, renginių (sporto, ivvairių konkursų, partijų suvažiavimo ir t. t.) proga, i̦staigų užsakymu. Gaminti suvenyriniai metalo ir keraminiai medaliai, vazelès, odiniai bloknotèliai, albumai, piniginès, knygutès, raktų pakabukai, ypač populiarūs sveikinimo adresai (kartais puošti metalu, gintaru), metalo ceche - ženkleliai, prizai ir t. t. Suvenyrų poreikis buvo didelis, nes dažnai dovanoti ịvairiomis progomis. O tokių progų sovietinėje santvarkoje buvo itin daug. Ivairius prizus, medalius, ženklelius, jubiliejines juostas ir kitus suvenyrus dovanojo fabrikų, gamyklų, kombinatų, kolūkių darbo pirmūnams, brigadoms, įvairių sporto šakų sportininkams, nusipelniusiems artistams ir kitiems ${ }^{55}$.

\section{Suvenyriniai ženkleliai sovietmečiu}

Suvenyrinių dirbinių kontekste išsiskiria ženklelių gamyba. Jie masiškai gaminti įvairioms progoms paminèti, šventėms, renginiams, organizacijoms. Taigi verta trumpai apžvelgti suvenyrinių ženklelių raidą Lietuvoje, tai išryškins, kaip keičiantis politinei santvarkai kartu kito ir ženklelio funkcija bei paskirtis.

Lietuvoje vienu pirmujų laikomas Motiejaus Valančiaus $1858 \mathrm{~m}$. blaivybės sajūdžio įsteigimo proga išleistas ženklelis ${ }^{56}$, nors būta ir

53 Dailes gaminiai (Vilnius: Lietuvos TSR liaudies ūkio tarybos centrinis techninès informacijos biuras, 1959); „Daile““: Kauno dailès darbu gamybinis kombinatas (Kaunas: „Daile““ kombinatas, 1966); Vilniaus kombinatas „Daile““(Vilnius: LTSR Dailès fondo Vilniaus „Dailès“ kombinatas, 1978); „Daile““: Kauno dailès darbu gamybinis kombinatas (Kaunas, 1981); „Daile““. Kauno kombinatas (Kaunas: Spindulys, 1991).

$541956 \mathrm{~m}$. Dailès fondo pasitarime ir $1958 \mathrm{~m}$. ịsakyme nurodyta parengti ir išleisti kombinatų gaminių reklaminius katalogus (albumus). Daugiau žr. TSRS Dailès Fondo Lietuvos skyriaus ir Vilniaus, Kauno bei Klaipėdos Kombinatų „Daile““ atsakingų darbuotojų pasitarimo, vykusio $1956 \mathrm{~m}$. vasario mèn. 18 d., Nutarimas, LLMA, F. 350, ap. 1, b. 108, 17; Lietuvos TSR Dailès Fondo İsakymas Nr. 32, Vilnius, 1958 m. gegužès 16 d., LLMA, F. 350, ap. 1, b. 108, 66-67.

55 Dargužaitè-Riškienè, „Vilniaus „Dailès“ kombinatas 1945-1990 m.“, 48.

56 Kolekcininkas A. Astikas nepateikè jokios papildomos nuorodos, kuo jis remiasi, šį ženkleli įvardydamas kaip pirmaji Lietuvoje, ir kur ši informacija užfiksuota, žr. Astikas, Lietuvos ordinai, 
ankstyvesnių pavyzdžių (Švč. Mergelès Marijos Nekaltojo Prasidèjimo pripažinimo proga, $1855^{57}$ ). Tai leidžia daryti prielaidą, kad ženkleliai Lietuvoje gaminti XIX a. antroje pusėje, tačiau jų išlikę mažai ir kol kas tyrimų šia tema neteko rasti. Kalbant apie XIX a. ženklelius, išimti sudaro JAV lietuvių bendruomenių išeivijoje gaminti (dažnai paramos tikslais) ženkleliai ${ }^{58}$. Tuo metu JAV kūrèsi daug lietuvių bendruomenių organizacijų, klubų, draugijų: 1890 m. veikė 60 šalpos draugijų, 1900 m. - apie 500 lietuviškų draugijų ir jų padalinių ${ }^{59}$. Lietuvoje ypač daug ženklelių pradèta gaminti tarpukariu. Jų gausai ittaką darè naujai besikuriančios organizacijos, draugijos, šventiniai, proginiai, propagandiniai renginiai ir t. t. Nepriklausomoje Lietuvoje veikè apie 780 draugijų ${ }^{60}$ ir dauguma jų turèjo savo ženklelius. Pasak muziejininko E. Remeco, ženklelis buvo neatsiejamas beveik kiekvienos Lietuvoje veikusios draugijos simbolis (kartu su draugijos ar organizacijos skiriamaisiais ženklais, tokiais kaip vèliava, antspaudas, uniforma arba jos dalis - kepurè $)^{61}$. Lietuvos universitete Kaune 1922-1940 m. buvo įregistruotos net 148 studentų organizacijos ${ }^{62}$. Ženkleliai gaminti įvairioms mokykloms, stovykloms, sporto varžyboms, šventėms, kongresams (pastarieji skirti atminimui ir registracijos mokesčio surinkimui ${ }^{63}$ ). Buvo leidžiami ir kaip rinkliavos (tai organizacijoms leisdavo papildyti savo iždą, rinkti lè̌as, pavyzdžiui, muziejaus statybai arba naujai įrangai ịsigyti), loterijos bilietų priedai arba suvenyrai $^{64}$. Pirmajji nepriklausomybès dešimtmeti ženkleliai dažniausiai gaminti užsienyje (Šveicarijoje, Vokietijoje, Čekoslovakijoje, Austrijoje), nes Lietuvos gamintojai negalejo pagaminti norimos kokybės ${ }^{65}$. Augantis jų poreikis skatino ir Lietuvoje pradèti steigti dirbtuves, galinčias patenkinti užsakovus. Vietinėse dirbtuvėse gaminti ženklelius buvo pigiau, tad ir kaina tapo patrauklesné ${ }^{66}$. Pasak muziejininkès Ritos Škiudienès, didžiają

medaliai ir ženkleliai 1918-1940, 12. Kodèl būtent Blaivybès sajūdžiui skirtas ženklelis laikomas pirmuoju lietuvišku ženkleliu, sunku pasakyti. Tačiau ši faktą, kaip savaime priimtiną, mini ir kiti, žr. „Ženklelis“, https://www.vle.lt/straipsnis/zenklelis/.

57 Astikas, Lietuvos ordinai, medaliai ir ženkleliai 1918-1940, 12.

58 Verkelienè, „Retesni mažosios faleristikos eksponatai“, 121.

59 Ibid.

60 Astikas, Lietuvos ordinai, medaliai ir ženkleliai 1918-1940, 32.

61 Remecas, „Lietuvos sukarintų organizacijų ženklai ir ženkleliai (1918-1940)“, 347.

62 Verkelienè, „Retesni mažosios faleristikos eksponatai“, 120.

63 Remecas, „Katalikiški ženkleliai tarpukario Lietuvoje“, 207-226.

64 Ibid., 207.

65 Ibid., 206.

66 Ženklelių kaina dažniausiai būdavo 1 Lt, tačiau jų savikaina, užsakant Lietuvos gamintojams, siekè apie 10-15 ct. Daugiau žr. Remecas, „Katalikiški ženkleliai tarpukario Lietuvoje“, 207. 

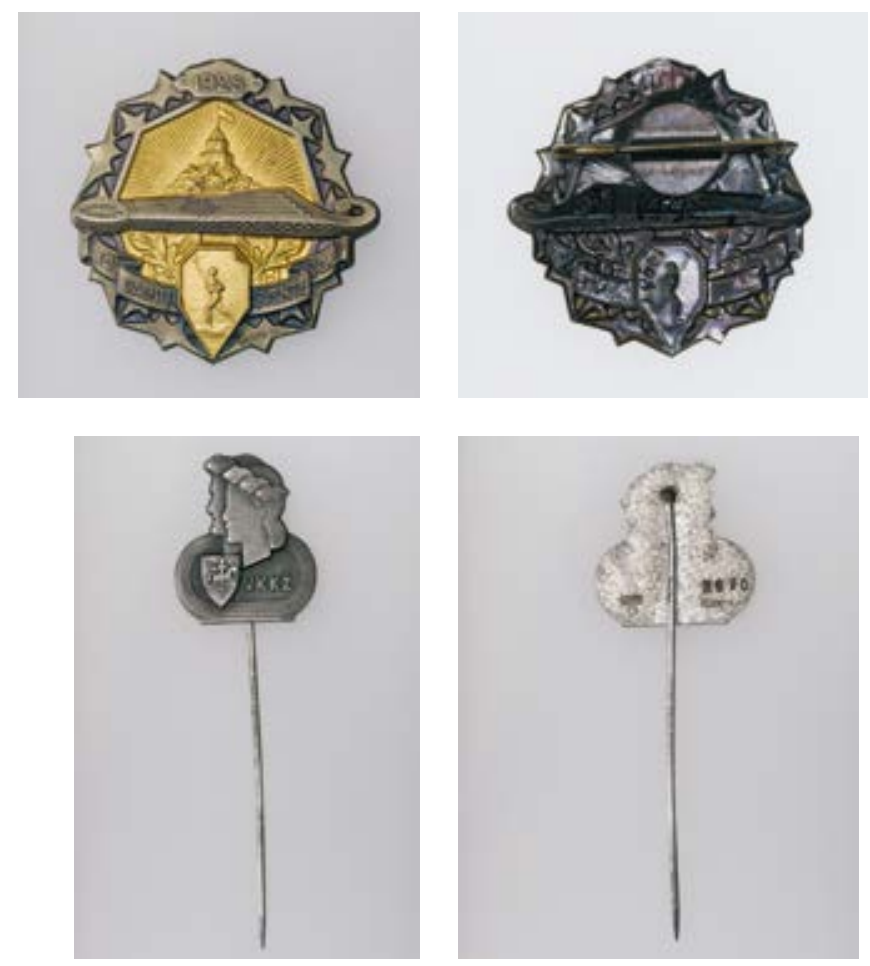

1.

Vytautas Bičiūnas, II-ji dainu šventè Kaune, ženklelis, 1928, vario ir cinko lydinys, auksavimas, $30 \times 30 \mathrm{~mm}$, gamintojas „Huguenin Frères \& Co“, Šveicarija, LNM, M 1998/1, Gedimino Trečioko nuotrauka, 2021

Vytautas Bičiūnas, The 2nd Song Festival in Kaunas badge, 1928, zinc-copper alloy, gilding

2.

Jonas Juozas Burba,

Valstybinis kūno kultūros ženklelis, 1936, sidabras, $21,5 \times 21 \mathrm{~mm}$, gamintojas „Huguenin Frères \& Co“, Šveicarija, nr. 2970, LNM, M 5189, Gedimino Trečioko nuotrauka, 2021

Jonas Juozas Burba, State Physical Culture badge, 1936, silver

dali gamino Kaune Juozo Gerštiko (Gerštyko; dirbtuvė veikẻ 1918-1938), Leizerio ir Moisiejaus Klionų (veikè 1923-1940), graverio Filypo Ivanovo ir Samuelio Zalsbergo, Lietuvos karo invalidams šelpti komiteto dirbtuvės, firma „Graviūra“ („Gravelit“), taip pat nežinomi juvelyrai AG, NF7 1940 m. atėjus ị valdžią sovietams, Lietuvoje pradèta sovietizacija, įmonių nacionalizavimas. Taigi nuo $1940 \mathrm{~m}$. spalio 5 d. nacionalizuota F. Ivanovo ir S. Zalsbergo dirbtuvė priklausė kooperatinei gamybinei ateljè „Graviūra“688.

Tarpukariu ženklų ir ženklelių projektus kūrè žymūs dailininkai Antanas Žmuidzinavičius, Vytautas Kazimieras Jonynas, Juozas Zikaras, Antanas Tamošaitis, Eleonora Lukštaitė-Marčiulionienė, Telesforas Kulakauskas ir kiti. Bene daugiausia jụ projektų sukūrė grafikas Jonas Juozas Burba ir dailininkas Vytautas Bičiūnas [1, 2 il.]. Projektų konkursuose

67 Rita Škiudienè, „Tam tikri tarpukario auksakalystès bruožai“, in Primityvumas mene (Vilnius: Kultūros ir meno institutas, 1999), 340, 345, 349, 353.

68 Rita Škiudienè, „Tarpukario Kauno žydų meistrų ịnašas į Lietuvos auksakalystę“, in Lietuvos žydų kultūros paveldas: kasdienybès pasaulis (Vilnius: Lietuvos kultūros tyrimų institutas, 2013), 450. 


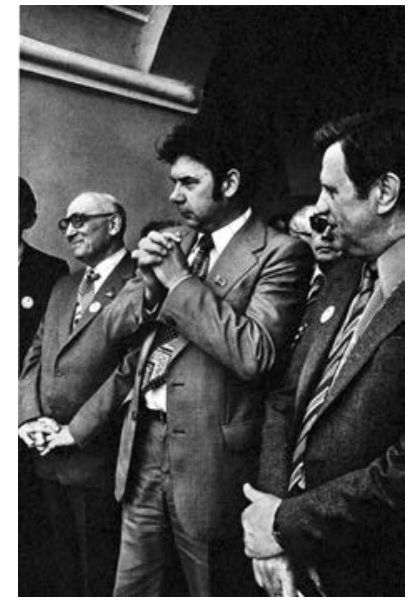

3.

„Tèviškès“ draugijos pirmininkas Pranas Petronis, poetai Juozas Nekrošius ir Justinas Marcinkevičius Knygos šventėje Vilniuje 1981 m., Algimanto Kunčiaus nuotrauka

Chair of the Téviške Society Pranas Petronis, poets Juozas Nekrošius and Justinas Marcinkevičius at the Book Festival in Vilnius in 1981, photo by Algimantas Kunčius

aktyviai dalyvavo ir Meno mokyklos mokiniai, pavyzdžiui, 1933 m. Eucharistijos karžygių ženklelio konkursui buvo pateikta 120 mokinių projektų ${ }^{69}$.

Tapukario ženkleliuose vaizduota organizacijų simbolika, pavyzdžiui, skautų - lelija, Šaulių sajungos - dvigubas kryžius skyde. Dažnas kanklių (naudotas choro, kanklių draugijos, dainų šventès ženkleliuose), Gedimino pilies bokšto (menantis Lietuvos istoriją) motyvas, ąžuolo lapų arba rūtų vainikas ar jo fragmentas, valstybinė atributika - trispalvė (arba jos spalvinis derinys), Vytis, Gediminaičių stulpai. Minėti motyvai dažnai derinti ženklelio kompozicijoje tarpusavyje, priklausomai nuo paskirties. Tuo metu gana dažnai naudota tautinè simbolika, siekiant formuoti nacionalinị identitetą ir žadinti patriotinius jausmus. Galima sakyti, kad ženkleliui būdinga deklaratyvi vaizduosena, atspindejjusi valstybès ar organizacijos pozicijas.

Sovietmečiu, reikia pastebèti, kad masinė ženklelių gamyba kartu tapo masiniu vaizdų reprodukavimu, per kurị skverbtasi ị visas žmogaus individualaus gyvenimo ir veiklos sritis - darbą, mokslą, laisvalaikį. Jau vaikai privalèjo mokykloje dèvėti ženklelius - spaliukų, vėliau pionierių, komjaunuolių. Neabejotinai juos segėdavo partijos nariai, taip pat įvairių darboviečių darbuotojai, pavyzdžiui, aptarnaujantis personalas restoranuose (Kauno restoranų-kavinių „Astra“ ir „Vakaras“ ženkleliai ${ }^{70}$ ), parduotuvėse (Trakų universalinės parduotuvės „Skaistis“"71). Iš renginių fotografijų

69 Remecas, „Katalikiški ženkleliai tarpukario Lietuvoje“, 219; Smilingytė-Žeimienė, „Šiek tiek apie mažiausius Lietuvos istorijos paminklus“, 40.

70 „Naujas muziejuje: restoranų ženkliukai“, https://kaunomuziejus.lt/parodos/naujasmuziejuje-restoranu-zenkliukai/.

71 Trakai numizmatikoje, 127. 


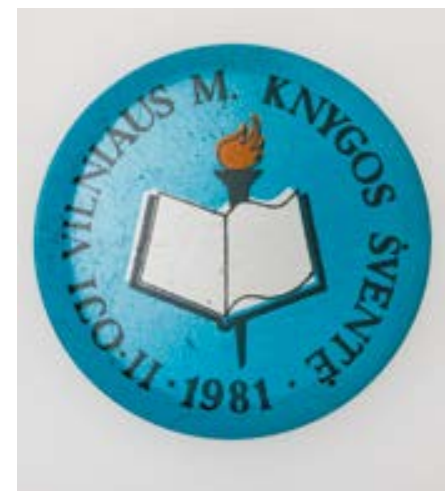

4.

II-oji Vilniaus m. knygos šventè, ženklelis, 1981, geležis, Ø 42 mm, gamintojas Talino „Norma“, LNM, M 4280, Gedimino Trečioko nuotrauka, 2021

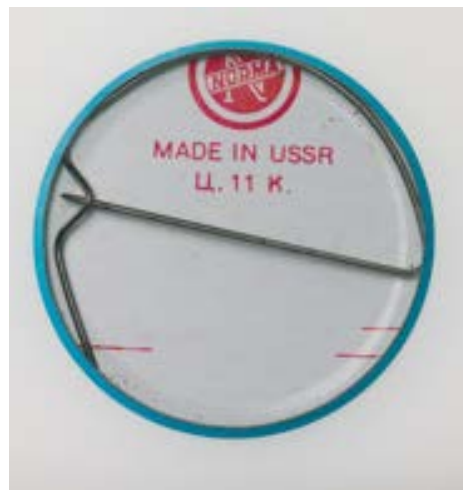

The 2nd Vilnius Book Festival badge, 1981, iron

galima pastebèti, kad vykstant įvairiems festivaliams, šventėms dalyviai dèvėdavo specialiai šiems renginiams užsakytus ir sukurtus ženklelius. Tačiau kai kurie segdavosi ne tik šventei skirtaji, bet ir su Lietuvos SSR vẻliava, tikriausiai taip išreikšdami savo lojalumą esamai santvarkai. Tai iliustruoja Algimanto Kunčiaus fotografija [3 il.], kurioje užfiksuota 1981 m. II Vilniaus knygos šventès akimirka, pagal ją pavyko rasti ir šio renginio ženkleli [4 il.], kuris buvo pagamintas ne Lietuvoje, o Talino gamykloje „Norma“. Jo ikonografijoje panaudotas dažnas bibliotekų, švietimo ir panašiu įstaigu simbolis - knyga ir fakelas. Tokị vaizdinị matome $1960 \mathrm{~m}$. F. Daukanto sukurtame ženklelyje Knygos bičiulis. Kokiam renginiui, įstaigai ar draugijai buvo sukurtas šis ženklelis, kol kas negalima atsakyti. Greičiausiai jis nebuvo skirtas klubui, nes, pasak vieno iš Vilniaus knygos bičiulių klubo steigejju Albino Vaičiūno, iki $1970 \mathrm{~m}$. Lietuvoje bibliofilu arba knygos bičiulių klubo oficialiai nebuvo ${ }^{72}$. Tačiau verta paminèti, kad sovietmečiu slapta veikusios organizacijos taip pat pasigamindavo ženklelių. Pavyzdžiui, Eucharistijos bičiulių draugijos narys Juozas Barysas apie 1974 m. Klaipèdos „Dailès“ kombinate užsakė išlieti metalinị ženklelị su koplytstulpiu, „kurị oficialiai buvo galima pateikti kaip liaudies meno motyvą “73. Tai tikriausiai buvo ne

72 Daugiau žr. Jurgis Stašaitis, Albinas Vaičiūnas ir Birutė Sriogytė-Vaitkienė, sud., Mažvydo klubas: Mažvydo knygos bičiuliu klubo pédsakais (Vilnius: Krantai, 2010), 12.

73 Regimanta Stankevičienè, „Paveikslas „Rožinio Švč. Mergelè Marija“ su aptaisais ir karūnomis“, in Lietuvos sakralinè dailè, t. 2, Šiauliu vyskupija, d. 2, Šiauliu dekanatas, kn. 1, Agailiai-Juozapava (Vilnius: Lietuvos kultūros tyrimų institutas, 2018), 276. 
vienintelis toks atvejis, tačiau tokio pobūdžio ženklelių funkcijos, gaminimo ir dėvèjimo specifika reikalautų atskiro tyrimo.

Tiriant ženklelių asortimentą, išryškẻja sovietiniu laikotarpiu vykusios šventès, propagandiniai, kultūriniai renginiai, sporto varžybos. Tokio tipo ženklai gali papasakoti apie sovietinès visuomenès gyvenimą, jie tarsi tam tikro istorinio laikotarpio ir jame vykusių ivvykių dokumentacija. 0 kompoziciniai meniniai sprendimai gali atskleisti nedaug tyrinètą ${ }^{74}$ mažo formato suvenyrinio dirbinio dizaino specifiką tuo metu. Ženklelių įvairovè ir gausa paskatino dar vieno fenomeno gimti - jų kolekcionavimą. Sovietiniu laikotarpiu ėmè daug kas domètis, rinkti ir kolekcionuoti ženklelius, kūrèsi faleristikos kolekcininku klubai. Periodinejje spaudoje (Valstiečiu laikraštis, Sportas, Vakaru ekspresas, Vakaru Lietuva, Šiauliu kraštas, Veidas, Šiauliu naujienos, Panevė̌zio rytas ir pan.) yra gana nemažai straipsniu apie kolekcininkus, daugiausia sovietmečiu pradejusius rinkti ženklelius, ir jų rinkinius.

Masinei ženklelių gamybai reikẻjo gamybinių pajėgumų ir dailininkų, kūrusių jų projektus. Jei tarpukario Lietuvoje iš pradžių jie gaminti užsienyje, vèliau - privačiose juvelyrų dirbtuvėse, tai i valdžią atėję sovietai nuo pirműjų dienų ėmè reorganizuoti ir steigti ịstaigas, „rūpinosi“ politišskai angažuotų kūrinių ir dirbinių užsakymais ir sklaida ${ }^{75}$. Vieni pagrindinių sovietmečiu ženklelių gamintojų buvo „Dailès“ kombinatai Vilniuje ir Klaipėdoje, nemažai ju gamino ir Telšiu „Praktika“ (ikurta 1965), metalo dirbtuvių ịmonė „Metalistas“ Kaune, meno gaminių įmonė „Ūla“ Druskininkuose, eksperimentinės dailiosios keramikos gamykla „Jiesia“, gamybinio meno verslų ir suvenyrų susivienijimo „Dovana“ padalinys Vilniuje, Šiaulių „Nuklonas“, Turistų klubo dirbtuvès Telšiuose. Tačiau panašu, kad ženklelių poreikis buvo itin didelis ir jie užsakinèti ne tik Lietuvoje, bet ir kitose SSRS respublikose: Talino gamykloje „Norma“, Rygos mechanikos gamykloje „Darbs“, Maskvos monetų kalykloje (Московский монетный двор). Tuo pačiu Lietuvos ženkleliu gamintojai gaudavo nemažai užsakymų iš kitų SSRS respublikų. B. Žaliausko kruopščiai sudarytame turistinių ženklelių kataloge užfiksuoti užsakovai - tai Ukrainos, Baltarusijos, Uzbekijos,

74 Straipsnio autorè magistro baigiamajame darbe skyrè keletą pastraipų faleristikos klausimui. Daugiau žr. Dargužaitè-Riškienè, „Vilniaus „Dailès“ kombinatas 1945-1990 m.“, 48-49.

75 Giedrè Jankevičiūtè, Po raudonaja žvaigžde: Lietuvos dailè 1940-1941 m. (Vilnius: Lietuvos kultūros tyrimų institutas, 2011), 233-235. 
Kazachstano, Azerbaidžano, Turkmėnijos ir kitų respublikų turistinės organizacijos ${ }^{76}$.

Ženkleliai i gamybą patekdavo tik po Meno tarybos ${ }^{77}$ sprendimo. Kai kurie jų, dažniausiai susiję su apdovanojimais už nuopelnus, buvo steigiami Lietuvos SSR Ministrų Tarybos, pavyzdžiui: LTSR gamybinès kooperacijos žymūnas (1946), LTSR liaudies švietimo pirmūnas (1957), LTSR draugovininkas žymūnas (1967) ${ }^{78}$ ir kitokie. Honoraras už ženklelio projektą siekė nuo 35 iki 120 rublių. Tiražai buvo iki 5000 vienetų. Jų pavyzdžiu autoriai dažniausiai nežinomi. Tačiau etalonus kūrẻ ir žymūs dailininkai, juvelyrai, dizaineriai: Feliksas Daukantas, Kazimieras Simanonis (g. 1937), Birutè Stulgaitė (g. 1952), Marytė Gurevičienè (g. 1951), Vytautas Zaturskis (1942-2013) ir kiti. Straipsnio autorei, pasitelkus techninius pasus, pavyko nustatyti sukurtus Birutės Stulgaitės, Marytės Gurevičienės, Kazimiero Simanonio, Vytauto Zarankos, Vido Kazimiero Gibavičiaus (1940-2020), Algimanto Ikamo, Alberto Krajinsko, Jono Stumbro ženklelių projektus.

Vilniaus „Dailès“ kombinate gamintus ženklelius buvo galima ịsigyti kombinato parduotuvėse ${ }^{79}$, kioskuose, tačiau jų nebuvo daug ir juos greitai išpirkdavo, labiausiai vertinti karšto emalio, jų kaina priklausė nuo spalvų kiekio. Ipprasta kaina buvo 21 kapeika, užlietas viena emalio spalva kainavo 30 kap., dviejų spalvų - 45 kap., trijų - 60 kapeikų. „Dailès“ kombinatų gaminti ženkleliai buvo kokybiški ir jie vertinti ${ }^{80}$, lyginant, pavyzdžiui, su Šiaulių ịmonės „Nuklonas“. Gaminta iš tombako (vario ir cinko lydinio), bronzos, žalvario, vario, aliuminio, dažnai dekoruota emaliu.

Ženklelių pavyzdžiuose atsispindi sovietinio laikotarpio gyvenimo aktualijos (minimos sukaktys, kultūriniai renginiai, šventės, sporto

76 Daugiau žr. Lietuvos TSR ženkliuku katalogas: Turizmas, 118-156.

77 Tiek „Dailès“ kombinatų, tiek kitų meno dirbinių ịmonių dirbiniai patekdavo ị gamybą tik po Meno tarybos vertinimo ir sprendimo. Meno taryboms vadovavo ir jose dalyvavo iškiliausi šalies dailininkai, skulptoriai, architektai, menotyrininkai, specialistai, turintys mokslinius laipsnius, taip pat kombinato dailininkai. Daugiau žr. Jonas Bubnys ir Vincas Jasiukevičius, Dailioji keramika Lietuvoje (Vilnius: Mokslas, 1992), 90-91; Rasa Dargužaitè, Meno pramone. „Dailès“kombinatu veikla (Vilnius: Vilniaus aukciono biblioteka, 2020), 39; Dargužaitė-Riškienè, „Vilniaus „Dailès“ kombinatas 1945-1990 m.“, 42-44.

78 Kęstutis Lapinskas, „Ženklelis“, in Tarybu Lietuvos enciklopedija, t. 4 (Vilnius: Vyriausioji enciklopedijų redakcija, 1988), 668; Baronas, Lietuvišku garbès ženklų katalogas, 54, 60.

79 Vilniaus „Dailès“ kombinatui priklausė septynios parduotuvės Lietuvoje. Vilniuje veikè keturios - Pamėnkalnio g. 1 (buvusi P. Cvirkos g.; dabar Pamėnkalnio galerija), Vokiečių g. 2 (buvusi Muziejaus g.; dabar Dailininkų sajungos galerija), Gedimino pr. 1 ir Kauno g. 36.

80 Pokalbis su doc. dr. Kęstučiu Skeriu, faleristikos kolekcininku, Lietuvos olimpinès kolekcininkų asociacijos viceprezidentu. Užrašè R. Dargužaitè, 20200526. 


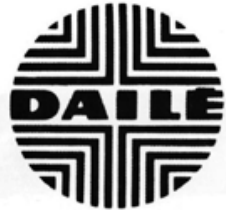

5.

Teresė Bajorūnaitè-Lekienė, Vilniaus „Dailès“ kombinato ženklas, 1968, in Audrius Klimas, Lietuvos prekiu ženklai: istorija, funkcija, klasifikacija, Vilnius: Vilniaus dailès akademijos leidykla, 2009, il. 87

Teresė Bajorūnaitė-Lekienè, Logo of the Vilnius Daile Art Production Factory, 1968

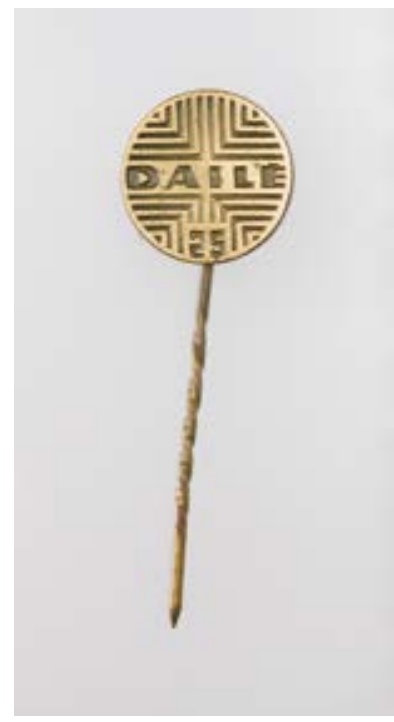

6.

Ženklelis, skirtas Vilniaus „Dailès“ kombinato 25-mečiui, apie 1970, vario ir cinko lydinys, $\emptyset$ 11,6 mm, gamintojas Vilniaus „Dailès“ kombinatas, LNM, SM 925, Gedimino Trečioko nuotrauka, 2021

Badge dedicated to the 25th anniversary of the Vilnius Dailè Art Production Factory, 1970, zinc-copper alloy

varžybos), miestą reprezentuojantys objektai (vaizduoti ne tik architektūriniai paminklai, bet ir modernūs pastatai) ir kita. Peržvelgus faleristikos rinkinius, išryškejja jų dizaino įvairovè. Kuriant nedidelio formato dirbinį, reikalingas specifinis meninis sprendimas - apibendrinta, simbolinè, bet kartu aiški, informatyvi ikonografija. Ženklelio kūrimo principas turinio ir kompozicine prasme labai artimas emblemai (prekiniam ženklui). Pastebèta, kad dažnai emblema (organizacijos, renginio ir pan.) perkeliama ị ženklelio formatą. Dailininkas sukurdavo ịstaigai logotipą, firminį blanką, voką ir ženklelį⒈ Arba sukurtas įmonès (pvz., Vilniaus „Dailès“ kombinato ženklas [5, 6 il.], Teresè Lekienė, $1968^{82}$ ), renginio (pvz., Respublikinės moksleiviu

81 Pavyzdžiui, Rimanto Dichavičiaus sukurtas Vilniaus rašytojų memorialinio muziejaus ženklas, firminis blankas, vokas ir ženklelis. Žr. Vaizduojamosios dailès Meno tarybos posėdžio Protokolas Nr. 26, Vilnius, 1981 m. gruodžio mèn. 7 d., UAB „Vilniaus daile““ archyvas (Kauno g. 36, Vilnius), 38. 


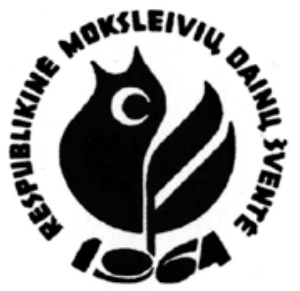

Algimantas ir Vytautas Nasvyčiai, Respublikinès moksleivių dainų šventès ženklas, 1964, in Audrius Klimas, Lietuvos prekių ženklai: istorija, funkcija, klasifikacija, Vilnius: Vilniaus dailès akademijos leidykla, 2009, il. 242

Algimantas Nasvytis and Vytautas Nasvytis, Logo of the Republican Schoolchildren's Song Festival, 1964

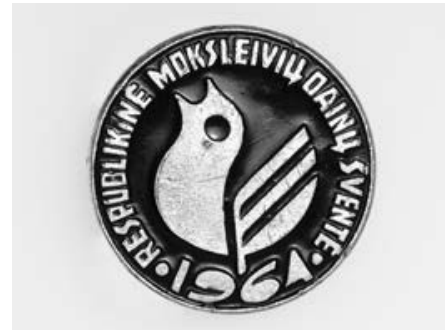

8.

Respublikinè moksleiviu dainu šventè, ženklelis, 1964, aliuminis, emalis, Ø 21,3 mm, LNM, SM 1940, Gedimino Trečioko nuotrauka, 2021

Republican Schoolchildren's Song Festival badge, 1964, aluminium, enamel

dainų šventès [7, 8 il.], 1964; Dainų šventès, 1985; abiejų autoriai Algimantas ir Vytautas Nasvyčiai ${ }^{83}$ ) logotipas buvo pritaikomas ir perkeliamas ị ženklelio formatą. Kartais emblemą sukurdavo vienas dailininkas, o ženklelị - kitas. Pavyzdžiui, renginio „Dailès dienos“ emblemą sukūrè dizaineris Pranas Markevičius $^{84}$, o 1986 m. ženklelio etaloną - juvelyrė Birutė Stulgaite் ${ }^{85}$.

Pagal tematiką būtų galima išskirti keletą ženklelių rūšių: sporto, suvenyriniai miesto, kultūrinių renginių, įstaigų, proginiai, propagandiniai. Sporto ženkleliai gaminti kiekvienų varžybų (krepšinio turnyrų, moterų rankinio taurès, šachmatų, gimnastikos, irklavimo, spartakiadų ir t. t.) [9-11 il.] Lietuvoje ir kitose respublikose proga. Jie pardavinèti renginio vietoje (pvz., Vilniaus sporto rūmuose) ${ }^{86}$. Sporto varžyboms skirtuose ženkleliuose dažniausiai vaizduotos stilizuotos, schematiškos sportininkų figūros, sporto šaką pristatantis simbolis (kamuolys, šaškès, irklai, šachmatas ir pan.), vieta (dažnas stadiono motyvas) arba tik varžybų pavadinimas (pvz., K. Simanonio ženklelis FILA, Tarptautiniam J. Paddubno imtynių turnyrui,

82 Klimas, Lietuvos prekiu ženklai, il. 87.

83 Ibid., il. 242, 244.

84 Ibid., il. 155.

85 Taikomosios dekoratyvinès dailès pasas, patvirtintas Dailès fondo modelių-etalonų meno tarybos Protokolo Nr. 3, 198604 03, Asociacijos LATGA archyvas.

86 Pokalbis su Kęstučiu Skeriu. Užrašè R. Dargužaitė, 20200526. 


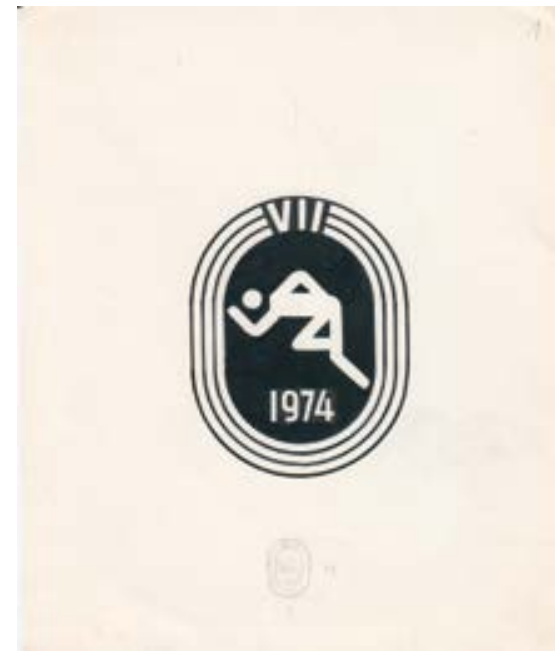

9.

Feliksas Daukantas, Aukštuju mokyklu 7-oji Spartakiada, ženklelio projektas, 1974, Vilniaus dailès akademijos bibliotekos rankraščiu skyrius, Felikso Daukanto archyvas, F. 3-251, 1. 1-2

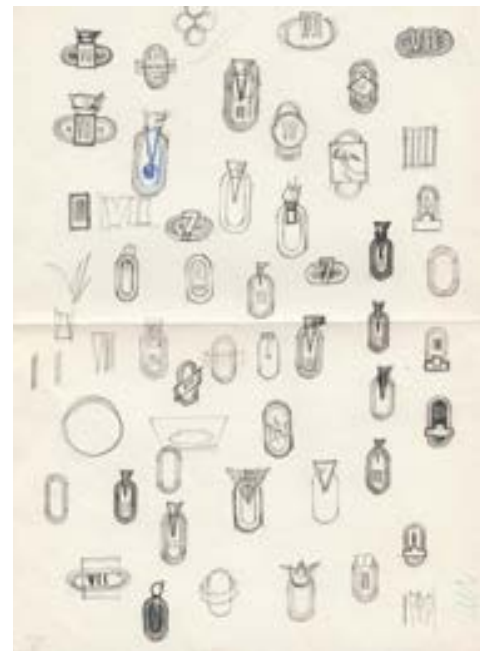

Feliksas Daukantas, The 7th Spartakiad of Schools of Higher Education badge design proposal, 1974

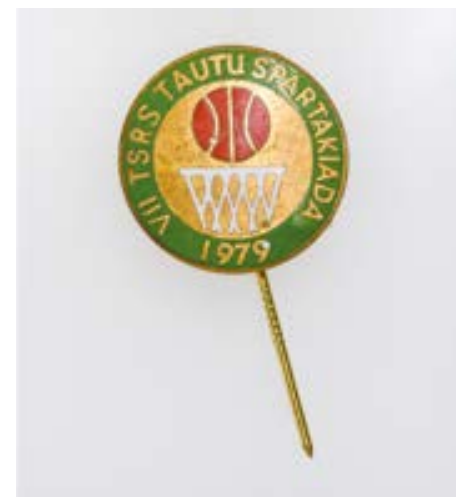

10.

VII TSRS tautu spartakiada, ženklelis, 1979, vario ir cinko lydinys, emalis, Ø $19 \mathrm{~mm}$, gamintojas Vilniaus „Dailès“ kombinatas, LNM, SM 1124, Gedimino Trečioko nuotrauka, 2021

The 7th Spartakiad of the Peoples of the USSR badge, 1979, zinc-copper alloy, enamel

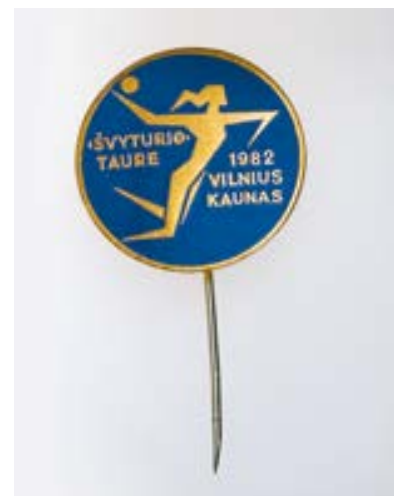

11.

Moteru rankinio varžybu „ک̌svturio“ taurè, ženklelis, 1982, bronza, emalis, Ø 21,2 mm, gamintojas Vilniaus „Dailès“ kombinatas, LNM, SM 3018, Gedimino Trečioko nuotrauka, 2021

Women's handball competition for the Švyturys cup badge, 1982, bronze, enamel 


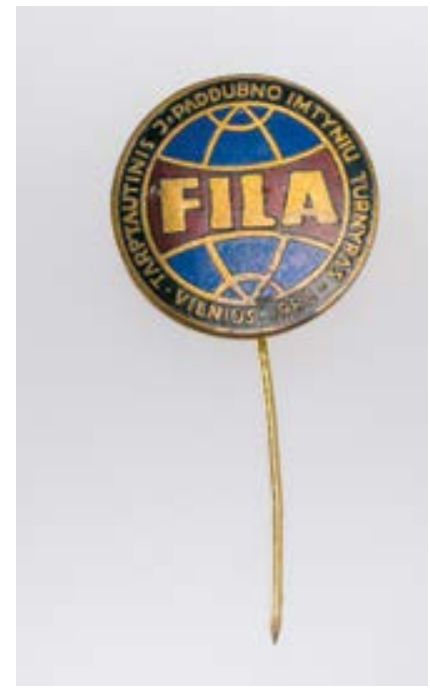

\author{
12. \\ Kazimieras Simanonis, Tarptautinis J. Paddubno imtyniu \\ turnyras, ženklelis, 1983, vario ir cinko lydinys, emalis, \\ $\emptyset 19,8$ mm, gamintojas Vilniaus „Dailès“ kombinatas, LNM, \\ SM 2863, Gedimino Trečioko nuotrauka, 2021 \\ Kazimieras Simanonis, J. Poddubny International Wrestling \\ Tournament badge, 1983, zinc-copper alloy, enamel
}

1983 [12 il.]). Sovietmečiu plačiai skatintas turizmas, veikè îvairūs klubai, bazės, rengtos stovyklos, sąskrydžiai ir t. t. Tačiau i̇domu pažymèti, kad tuo metu turizmas buvo ne tik laisvalaikio leidimo būdas, bet ir tam tikra kraštotyros forma - žygių metu siekta susipažinti su Lietuvos istorija ${ }^{87}$. Pasak muziejininko G. Džiovėno, iki $1991 \mathrm{~m}$. buvo išleista apie $500 \mathrm{su}$ turizmu susijusių ženklelių ${ }^{88}$. Juose [13 il.] dažniausiai vaizduotas žygeivis su kuprine, schematiška palapinių eilè, tuo pačiu primenanti eglutės siluetą, kompasas, o kartais visi minèti elementai vienoje kompozicijoje derinti su tekstu, kuriame nurodyta, kokiai progai ženklelis skirtas. Specifinėms turizmo šakoms vaizduoti būdingi objektai: vandens turizmo - baidarès arba tik irklai, žiemos žygių - slidès ir panašiai. K. Simanonis sukūrè ženklelių „Nemuno“ [14 il.] turistų draugijos 1966-1971 m. vykusiems sąskrydžiams ${ }^{89}$. Moksleivių turistų republikiniams sąskrydžiams „Taika ir draugyste““ ženklelius 1960-1964 m. kūrè F. Daukantas ${ }^{90}$, 1969-1975 m. - V. K. Gibavičius ${ }^{91}$.

Ženkleliai buvo ịvairiausių formų ir stilių. Naudota įmantri, kone barokiška arba aiški, lakoniška kaligrafija, nors jie galejo būti sukurti tame pačiame dešimtmetyje. Suvenyriniuose miesto ženkleliuose vyravo

87 Džiovėnas, „Lietuvos turizmo istorija ženkleliuose ir medaliuose“.

88 Ibid.

89 Žr. Lietuvos TSR ženkliukų katalogas: Turizmas, 96-98.

90 Ibid., 108-110.

91 Ibid., 110-112. 
LTSR TURIST INIAI ŽENKLIUKAI

1etuvos turistas

$17 \times 16,1 \mathrm{~mm}$, geltonas met.

karăta em.: 1965

rub. $-\mathrm{b} \theta 1 \mathrm{ta}-2 \mathrm{e} 11 \mathrm{~s} \mathrm{k}$.

nedaz, -belta-zel1a $s$.

rub, -belte-zeliesk.

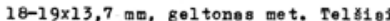

xelts

juodintag, raud.
balta-zalis

juodints

Juodintas, raud.

TKD

inci-

$-19,5 \times 14,5-15 \mathrm{~mm}$, geltonas Tel $\mathrm{x}_{\mathrm{i}}$

met.

Solte em.:

juodintas, raud.-balta-zalia

melyne-raud. -bel ta-zallo raud onas met. mel.-raud.-

7xl2 $\mathrm{mm}$ baltos stikles

melyna-juods (segt.)

juoda (smeigt.)

Sisu-

1101

nas"

turist (Typuot)

S1 ou-

v17x12

rausve-juods zेel1 o- Juode

raud one- juods $v 1010 t-$ Juod

gelt.żalia- melyna-juode

11 a 1
Nuklo-

nas"

Tel xiei

Lieturos turis tes - LRTE

zonklolis be pavadinimo

o17,1 mm, geltonas met.

balto lak. zel.sk., 2ak.

8 rausvak.,jak, melyne sk., iak.

13

LTSR turistiniai ženkliukai, in Lietuvos TSR ženkliuku katalogas: Turizmas, sudarẻ Bronius Žaliauskas, [maketas parengtas spaudai su originaliais B. Žaliausko piešiniais], Vilnius, 1989, mašinraštis, Lietuvos nacionalinio muziejaus archyvas, F. NM, Apr. m., b. 278, p. 8-9

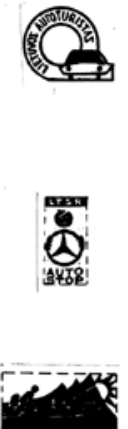

Lieturos autotur1s to

$18 \times 21,4 \mathrm{~mm}$.

geltones met.

talta en.:

fuodintes, 2 ells

raud.sk.-2alia sk. -bal to L.K1nalla sk.-balta-raud.8k. O1neo

LYSR autostopas (turizmo Telria pekellui vaziuofenor

TKD L.Kin-
dzia - $1961 \mathrm{m.})$ $21 \times 10,4 \mathrm{~mm}$,

gel tonas met.

rudintas

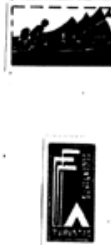

Dviracip tur1zmas

geition

Selta em : :

Juodintas, raud on a

Telr1:1

TKD

Suvalk1 jos turistas

$23 \times 11 \mathrm{~mm}$

coltonas mot.

fotooheminis

payiršsus rudes

vilniue

LTSR tur1ota

$20,5 \times 18,5 \mathrm{~mm}$,

balta serde, daz.

Sol ta em. :

Juoda-balta-ždara

LSSR tourist badges, in Lietuvos TSR ženkliuku katalogas: Turizmas

14.

Kazimieras Simanonis, III „Nemunas“ turistu sąskrydžio Anykščiuose ženklelis, 1967, bronza, $18,6 \times 19,6$ mm, LNM, SM 7186, Gedimino

Trečioko nuotrauka, 2021

Kazimieras Simanonis, Badge of the 3rd

Nemunas Tourist Congress in Anykščiai, 1967, bronze 


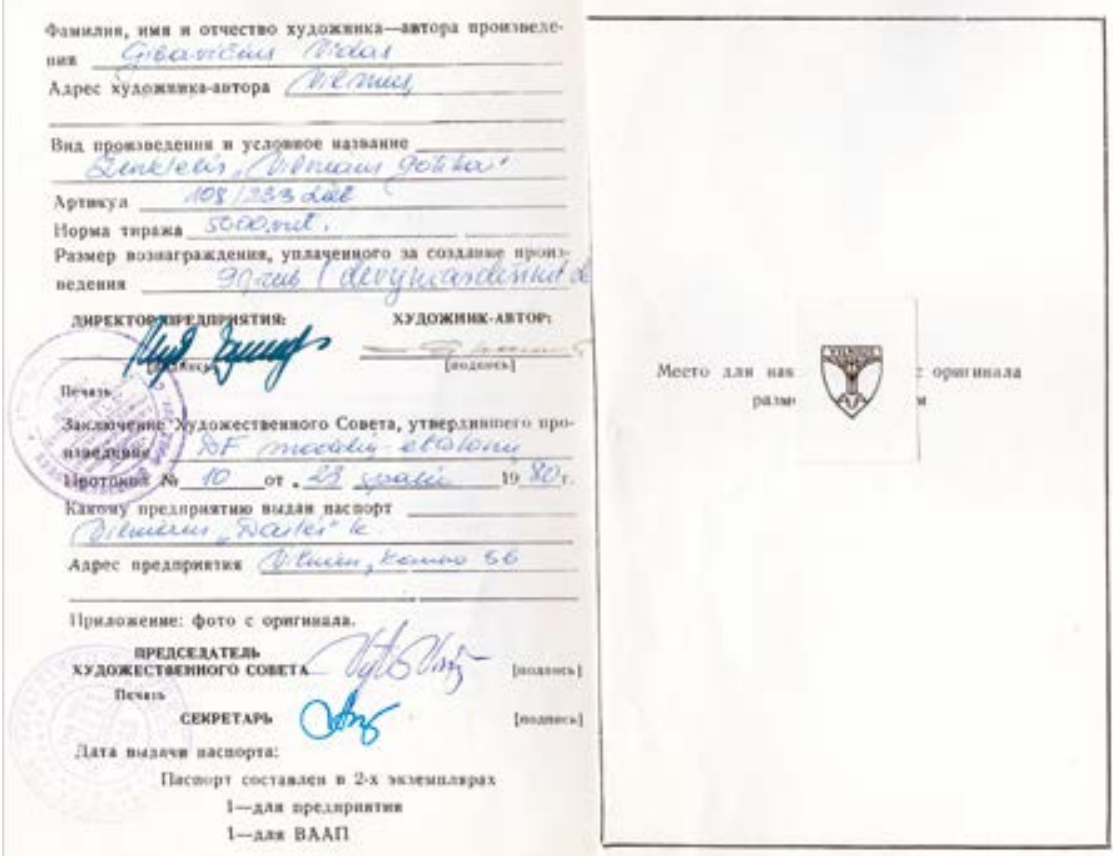

15.

Vido Kazimiero Gibavičiaus ženklelio Vilniaus gotika Taikomosios dekoratyvinès dailès pasas, 1980, Asociacijos LATGA archyvas
Applied Decorative Art certificate of Vilnius Gothic badge by Vidas Kazimieras Gibavičius, 1980

reprezentaciniai architektūros paminklai arba tik pastato motyvas - kolona, skliautas ir panašiai. Pastarojo tipo pavyzdžių sukūrė V. K. Gibavičius [15 il.]. Dailininko ženkleliai, skirti Vilniui, reprezentuoja miestą per stilių - gotiką (vaizduoja apibendrintą Šv. Onos bažnyčios siluetą) arba baroką (ženklelio forma atkartoja barokinès bažnyčios frontono detalę). Vilnių pristatant, naudotas ir modernaus miesto ịvaizdis - nauji modernūs pastatai (Operos ir baleto teatras, Sporto rūmai, Televizijos bokštas), skulptūros (pvz., Kazimiero Valaičio Vètrungè, Gedimino Karaliaus Rytas). Naudotas ir imaginacinis miesto peizažas, išskirtiniai objektai (pvz., dažnai Gedimino pilies bokštas arba tik jo formą imituojantis siluetas), miesto simboliai (pvz., Vilniaus ženkleliams būdingas geležinio vilko arba atpažistamo šv. Kristoforo vaizdavimas), kartais - augaliniai, ornamentiniai motyvai. Paprasčiausias vizualinis sprendimas apsiribodavo ịkomponuojant miesto herbą (Kauno 


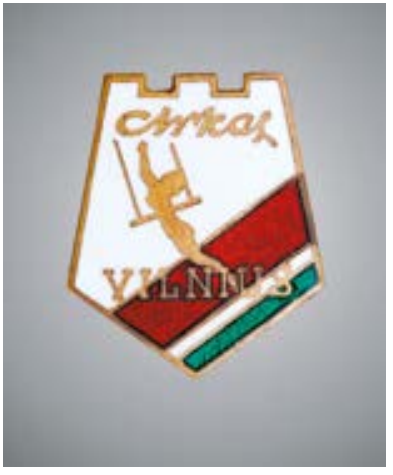

16

Feliksas Daukantas, Cirkas, ženklelis, XX a. 6 deš., vario lydinys, emalis, $20 \times 19 \mathrm{~mm}$, F. Daukanto šeimos nuosavybè, Tomo Kapočiaus nuotrauka, 2021

Feliksas Daukantas, Circus badge, 1960s, copper alloy, enamel

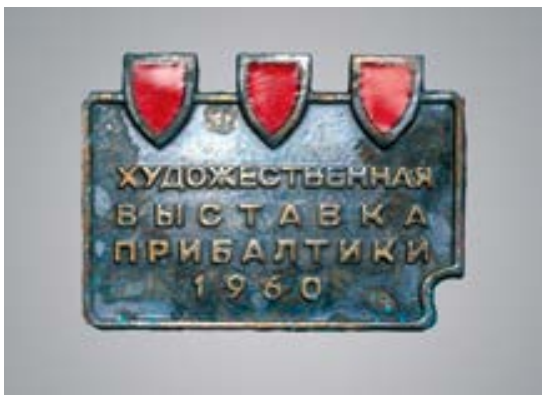

17.

Feliksas Daukantas, Pabaltijo meno paroda, ženklelis, 1960, sidabras, emalis, $15 \times 20 \mathrm{~mm}$, F. Daukanto šeimos nuosavybė, Tomo Kapočiaus nuotrauka, 2021

Feliksas Daukantas, Baltic Art Exhibition badge, 1960, silver, enamel

suvenyriniuose ženkleliuose - tauras raudoname fone, Klaipėdos - trys bokštai ant laivo korpuso ir pan.).

Kultūrinių renginių ženkleliai buvo skirti dainų šventèms ir festivaliams $^{92}$, šokių ansambliams ${ }^{93}$, teatro ${ }^{94}$, dailès ${ }^{95}$ ir klasikinès muzikos ${ }^{96}$ renginiams. Jų formos sprendimų būta įvairių, dažnai jos sietos su renginio tematika ar vieta. Pavyzdžiui, F. Daukanto ženklelio, skirto cirkui Vilniuje (XX a. 6 deš.) [16 il.], forma artima Gedimino pilies bokšto siluetui (per vizualą susiejama renginio vieta - Vilnius). Kitas pavyzdys - ženklelis Pabaltijo meno parodai (dail. F. Daukantas, 1960) [17 il.], jo forma primena

92 Pavyzdžiui, Estradinės muzikos fetivalis Palangoje, 1977, Liaudies meno ir sporto šventė Spalis 50, 1967, Respublikinè dainų šventė Leninui 100, 1970, Folkloro festivalis Baltica, 1987, Dainu šventė Klaipėdoje, 1961, Kauno miesto dainų šventė, 1974, Respublikinė moksleivių dainų šventė, 1974.

93 Pavyzdžiui, Dainų ir šokių ansamblio „Nemunas“ 50-mečiui, ansamblių „Rūta“, „Šviesa“, 1964, „Lietuva“, 1982, ženkleliai.

94 Pavyzdžiui, Teatro festivaliui Vilniuje, 1984, saviveiklinio teatro meno konferencijai Vilniuje, 1982, Valstybinio dramos teatro, Kauno valstybinio muzikinio teatro, 1965, Pabaltijo teatru festivalio, 1984, ženkleliai.

95 Pavyzdžiui, Keramikų simpoziumo Vilniuje, 1971, III Baltijos grafikos trienalès dalyvio, LTSR dailininkų suvažiavimo, 1984, ir kt. ženkleliai.

96 Pavyzdžiui, Kamerinès muzikos festivalio, 1967, Tarptautinio B. Dvariono jaunujų pianistų ir smuikininkų konkurso, Valstybinės filharmonijos simfoninio orkestro, 1980, ženkleliai. 


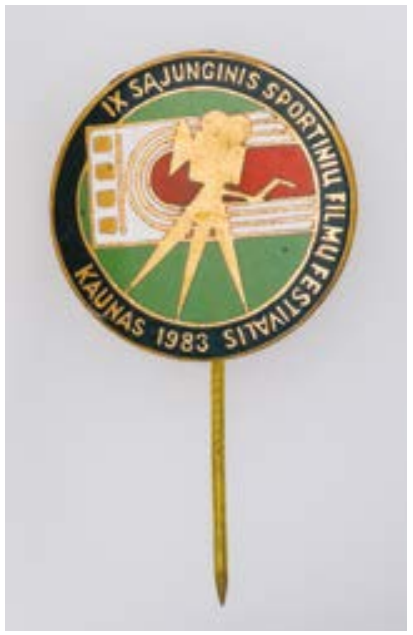

18.

Birutè Stulgaitè, IX sajunginis sportiniu filmu festivalis, ženklelis, 1983, bronza, emalis, Ø 20,5 mm, gamintojas Klaipèdos „Dailès“ kombinatas, LNM, SM 1981, Gedimino Trečioko nuotrauka, 2021 Birutè Stulgaitè, The 9th All-Union Sports Film Festival badge, 1983, bronze, enamel

paletę (nuoroda ị renginio tematiką), o trys raudonu emaliu dengti skydai simbolizuoja tris Baltijos šalis. Juvelyrių B. Stulgaitès (Sportinių filmų festivaliui, 1984) [18 il.], M. Gurevičienès (XIV sajunginiam kino festivaliui, 1981) projektuose vyrauja renginius pristatantys objektai (kino juosta, filmavimo kamera ir pan.), kompozicijoms būdingas estetiškas, minimalus grafinis sprendimas. V. Zarankos ženklelių projektams artimos geometrizuotos formos. Pavyzdžiui, ženklelyje Lietuvos architektūra ir statyba, skirtame Berlyno parodai, [19 il.] griežta kampuota linija kuriamas tarsi pastato siluetas (naujų namų, modernumo vizija) ir kartu plazdančios vèliavos imitacija, kurią patvirtina spalvinis sprendimas - raudona, balta, žalia.

Proginiai ženkleliai buvo skirti mokslo îstaigos baigimo proga [20 il.], įmonių sukaktims ir žymių žmonių jubiliejams paminèti. Mokslo įstaigu ženkleliai dažniausiai būdavo rombo formos su įstaigos ar jos fakulteto emblema, užrašu ir (arba) profesiją atspindinčiu simboliu: konservatorijos arfa, medicinos - taurè su apsivijusia gyvate, žemès ūkio - krumpliaratis, varpų vainikas, hidromelioracijos - teodolitas ir panašiai. Kartais ženkleliuose komponuotas Lietuvos SSR herbas, vėliava arba penkiakampė žvaigždė.

Panašu, kad kiekviena įmonè tikriausiai privalèjo užsisakyti atminimo ženklelį ir (arba) kitą suvenyrinį dirbinị, pažymint sukaktį. Tai patvirtina išlikusių ženklelių pavyzdžiai ${ }^{97}$. Nepropagandiniai žymių Lietuvos

97 Tai rodo gausus LNM faleristikos rinkinio kartotekoje aprašytų ženklelių kiekis.

Pateiksime tik kelis pavyzdžius: Šiaulių odos ir avalynės fabriko „Elnias“ 25-mečio, Vilniaus autobusų parko kontoros Nr. 1 25-mečio proga, Kauno šlifavimo staklių gamyklos 100-mečiui, 1969, Alytaus mašinų gamyklai - 40, 1966, žurnalui „Švyturys“ - XX metų, 1969, laikraščiui „Vilnis“ - 50, 1975 ir t. t. 


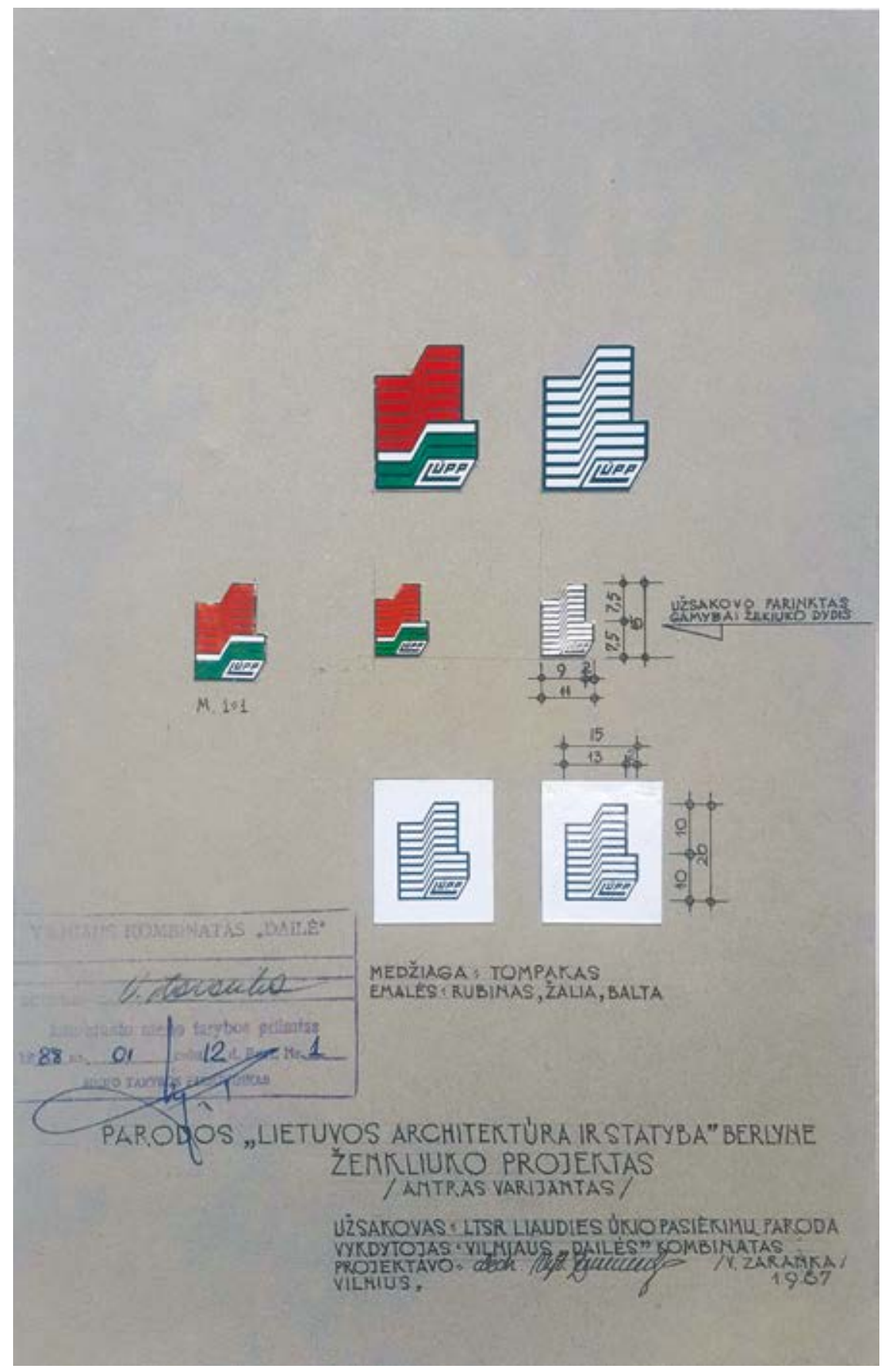

19.

Vytautas Zaranka, parodos Lietuvos architektūra ir statyba Berlyne ženklelio projektas, 1987, V. Zarankos šeimos nuosavybè
Vytautas Zaranka, Design proposal of the badge of the exhibition Lithuanian Architecture and Construction in Berlin, 1987 

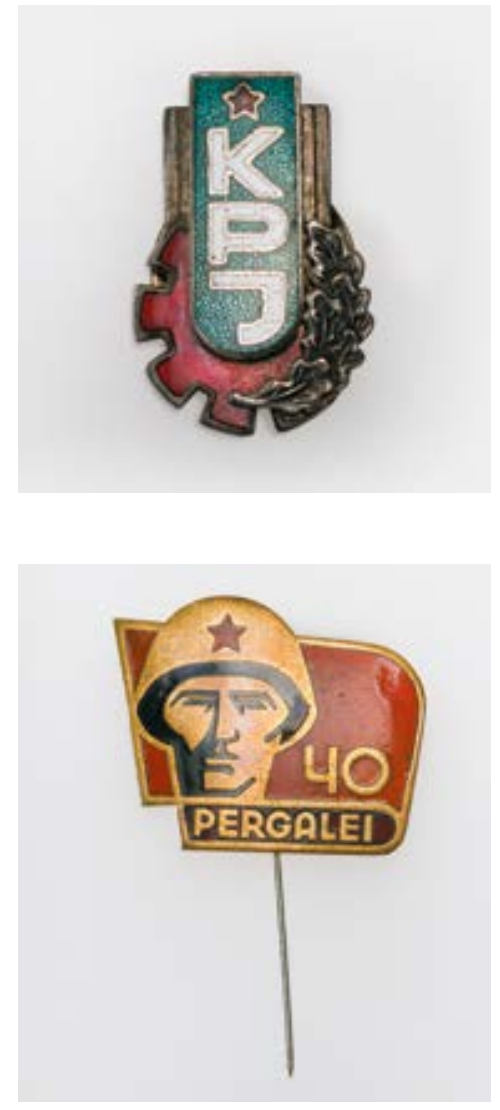

21.

Algimantas Ikamas, Pergalei -40 , ženklelis, 1985 , bronza, emalis, $25,6 \times 32 \mathrm{~mm}$, gamintojas Klaipėdos „Dailès“ kombinatas, LNM, SM 1750, Gedimino Trečioko nuotrauka, 2021

Algimantas Ikamas, 40 Years to Victory badge, 1985 , bronze, enamel
20.

Kauno politechnikos instituto ženklelis, 1960, sidabras, emalis, 23,3 × 15,4 mm, gamintojas Klaipèdos „Dailès“ kombinatas, LNM, SM 806, Gedimino Trečioko nuotrauka, 2021

Badge of the Kaunas Polytechnic Institute, 1960, silver, enamel

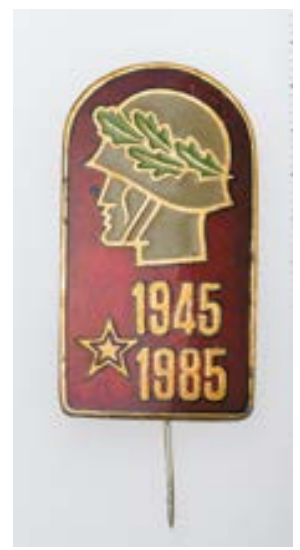

22.

Algimantas Ikamas, Pergalei - 40, ženklelis, 1985, bronza, emalis, $40 \times 22 \mathrm{~mm}$, gamintojas Klaipédos „Dailès“ kombinatas, LNM, SM 1756, Gedimino Trečioko nuotrauka, 2021

Algimantas Ikamas, 40 Years to Victory badge, 1985, bronze, enamel

kultūros žmoniu jubiliejiniai ženkleliai (Laurynui Gucevičiui, Simonui Daukantui, Liudvikui Rèzai, M. K. Čiurlioniui, Žemaitei, Ievai Simonaitytei, Kristijonui Donelaičiui, Juozui Tumui-Vaižgantui ir kt.) kurti minint gimimo arba mirties sukaktis.

Ypač daug gaminta propagandinių, skirtų paminèti V. Lenino gimimo sukaktis, partijos suvažiavimo proga (pvz., XXVII TSKP suvažiavimui), 


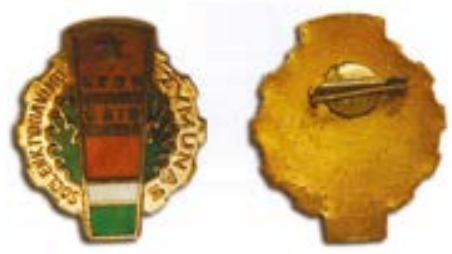

23.

Soclenktyniavimo žymūno ženklelis ir pažymèjimas, $\mathrm{XX}$ a. apie 6 deš., in Andrius Baronas, Lietuvišku garbès ženklu katalogas, Kaunas: V. Staniulio knygynas, 2018, p. 95

Socialist emulation leader badge and certificate, $1960 \mathrm{~s}$
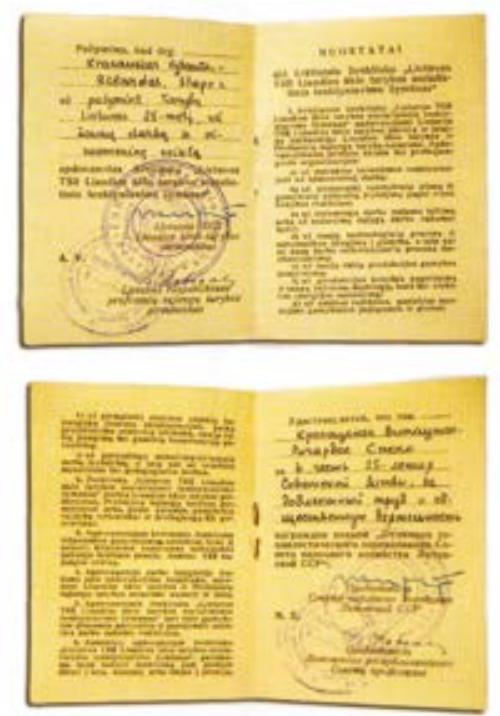

Antrojo pasaulinio karo pergalei, Lietuvos „istojimui“ i Sovietų Sajungą. Jiems būtų priskirtini ir vadinamieji apdovanojimų ženkleliai - darbo veteranui, už aplinkos tvarkymą, nusipelniusiam darbuotojui, darbo spartuoliui, žymūnui ir t. t. Proginiuose ženkleliuose naudota sovietinė atributika - penkiakampè žvaigždè, pjautuvas ir kūjis, V. Lenino portretas, kovinga, veržli sovietinio kario figūra arba portretas; proginiai užrašai - „40 pergalei“, „40 išvadavimas“, „Leninui 110“ ir pan., taip pat vaizduotas gvazdiko žiedas, amžinoji ugnis arba fejerverkai, simbolizuojantys šventinę nuotaiką. Dažnai naudotos Lietuvos SSR vèliavos spalvos - raudona, balta, žalia.

Ženkleliuose, skirtuose Pergalès 40-mečiui [21, 22 il.], vaizduojamas kario su šalmu siluetas, sovietinę atributiką patvirtinanti penkiakampè žvaigždè, ịrašas - minimos progos data, vieno iš jų forma imituoja plazdančią vèliavą (abiejų aut. Algis Ikamas, 1988), jų fonas raudonas - nuoroda i SSRS vèliavą. Tai vienas iš pavyzdžių, kaip minimaliomis vaizdinėmis detalèmis ženklelio formoje suderinama siektina perteikti žinia. Verta paminèti, kad kuriantiems propagandinius ženklelius rekomenduota remtis laikytais pavyzdiniais paminklais, skulptūromis ${ }^{98}$.

Ženkleliai, skirti apdovanojimams, buvo teikiami kartu su pažymėjimu [23 il.], kuriame nurodyta, kam jis skirtas ir už kokius 
nuopelnus - „pažymint Tarybų Lietuvos 25-metị, už šaunų darbą ir visuomeninę veiklą apdovanotas ženkleliu „Lietuvos TSR Liaudies ūkio tarybos socialistinio lenktyniavimo žymūnas“99 arba suteikiant „Aukščiausios klasès specialisto vard[a] [100 ir panašiai. Juose vyrauja sovietinè atributika - Lietuvos SSR vėliava arba jos spalvinis fonas, kurie derinti su užrašu ir (arba) istaigos, profesijos simboliu.

Akivaizdu, kad ženklelių gamyba - tai dar vienas iš sovietinės ideologijos „vertybių“ îtvirtinimo įrankių, naudojant vizualią plotmę. Ne tik agitaciniuose ženkleliuose vyravo sovietinė atributika, bet ir kultūrinių renginių bei kituose ženkleliuose propagandinis elementas reiškėsi per spalvinius sprendimus - naudojant Lietuvos SSR ir SSRS vèliavų spalvas. Pavyzdžiui, turizmui skirtame ženklelyje vaizduojamos palapinès, kino filmų festivaliui - stadionas, kino juosta, suvenyriniame miesto ženklelyje architektūriniai pastatai ir kita nudažomi vėliavos spalvomis. Žvelgiant kaip ị dizaino objektą, galima išskirti keletą būdingų bruožų: apibendrintos, stilizuotos formos ir (arba) objektai, kartais tiesiogiai susiję su ženklelio paskirtimi arba vaizduojami kaip metafora; išgryninta minimali vaizduosena, vaizdas derinamas su tekstu.

\section{Išvados}

Apibendrinant galima pasakyti, kad masinis ženklelių gamybos ir paplitimo reiškinys neatsiejamas nuo socialinių faktorių ir politinès situacijos. Lietuvoje intensyvus ju poreikis pasireiške tarpukariu - kuriantis naujai valstybei - steigiant naujas organizacijas ir draugijas, mokslo įstaigas, paramai renkant lèšas, reikšmingoms valstybės datoms ir istoriniams ivvykiams paminèti, sporto renginiams ir dainų šventėms ir t. t. Išvardyti gamintų ženklelių pavyzdžiai kurti formuojant nacionalinị identitetą. Pasikeitus politinei situacijai - Lietuvą okupavus sovietams, pradètos nacionalizuoti įmonès, taip perimta ir tarpukario dirbtuvių gamybinė bazè. Ženkleliai sovietiniu laikotarpiu tapo vienu iš daugelio ideologijos diegimo būdų - per vaizdą ir simbolius skleisti ir tvirtinti propagandines idejas, skverbiantis i visas žmogaus gyvenimo sritis ir veiklas. Tačiau ne visuose ženkleliuose vyravo akivaizdi sovietinė agitacija ir propagandinis turinys. Galima sakyti,

99 Žr. Baronas, Lietuvišku garbès ženklu katalogas, 1946-1989, 95.

100 Ibid., 74. 
priklausomai nuo ženklelio paskirties, naudota socrealistinės arba modernistinès dailès raiška, oparto fragmentai ir panašiai. Ženklelių atvejis įdomus ir vertas demesio kaip dar vienas sovietiniu laikotarpiu vyravusio dizaino pavyzdys ir kartu socialinio gyvenimo atspindys.

Gauta 20210720 


\section{Šaltiniai}

Asociacijos LATGA archyvas, Jono Basanavičiaus g. 4B, Vilnius. Taikomosios dekoratyvinès dailès pasai.

Dargužaitè-Riškienè, Rasa. „Vilniaus „Dailès“ kombinatas 1945-1990 m.: organizaciniai veiklos aspektai“. Magistro baigiamasis darbas, Vilniaus dailès akademija, 2020.

Felikso Daukanto (1915-1995) archyvas, šeimos nuosavybè.

Lietuvos literatūros ir meno archyvas. F. 350. LSSR dailès fondas.

Lietuvos TSR ženkliuku katalogas: Turizmas. Sudarė Bronius Žaliauskas, [maketas parengtas spaudai su originaliais B. Žaliausko piešiniais]. Vilnius, 1989. Mašinraštis. Lietuvos nacionalinio muziejaus archyvas. F. NM, Apr. m., b. 278.

Pokalbis su doc. dr. Kęstučiu Skeriu, faleristikos kolekcininku, Lietuvos olimpinès kolekcininkų asociacijos viceprezidentu. Užrašė R. Dargužaitè, 20200526.

$\mathrm{UAB}$ „Vilniaus daile“ archyvas, Kauno g. 36, Vilnius. Meno tarybos posèdžių Protokolai.

Vilniaus dailès akademijos bibliotekos rankraščių skyrius. F. 3. Felikso Daukanto archyvas.

Vytauto Zarankos (1933-2021) archyvas, šeimos nuosavybè.

\section{Literatūra}

Andriušis, Skirmantas ir Raimundas Petrikas. Lietuvos mokslo instituciju absolventu ženklai (1918-1989). Kaunas: Eurispauda, 2019.

Astikas, Algimantas. Lietuvos ordinai, medaliai ir ženkleliai 1918-1940. Vilnius: Mintis, 1993.

Baronas, Andrius. Lietuvišku garbès ženklu katalogas. Kaunas: V. Staniulio knygynas, 2018.

Bubnys, Jonas ir Vincas Jasiukevičius. Dailioji keramika Lietuvoje. Vilnius: Mokslas, 1992.

Budrikas, Aleksandras. „Dovana“. In Tarybu Lietuvos enciklopedija. T. 1, 447. Vilnius: Vyriausioji enciklopedijų redakcija, 1984.
„Daile“": Kauno dailes darbu gamybinis kombinatas. Kaunas: „Daile“ kombinatas, 1966.

„Daile“": Kauno dailès darbu gamybinis kombinatas. Kaunas, 1981.

„Daile“": Kauno kombinatas. Kaunas: Spindulys, 1991.

Dailes gaminiai. Vilnius: Lietuvos TSR liaudies ūkio tarybos centrinis techninès informacijos biuras, 1959.

Davis, Brian Leigh. Badges \& Insignia of the Third Reich 1933-1945. Poole, Dorset: Blandford Press, 1984.

Dargužaitè, Rasa. Meno pramonè. „Dailès“ kombinatu veikla. Vilnius: Vilniaus aukciono biblioteka, 2020.

Džiovènas, Gintaras. „Lietuvos turizmo istorija ženkleliuose ir medaliuose“. Lietuvos muziejai 2 (2003). Žiūrèta 2021 m. kovo $17 \mathrm{~d}$. http://www.museums.lt/Zurnalas/Dziovenas. htm.

Džiovėnas, Gintaras. „Turistiniai ženkleliai iki 1990 m. ir jų rinkimas“. In Lietuvos muzieju rinkiniai, 58-60. Vilnius: Etnomedijos spauda, 1999 .

Heller, Steven. Iron Fists: Branding the 20th Century Totalitarian State. New York: Phaidon Press, 2010.

Ideologinio darbo klausimai. Dokumentu rinkinys (1972-1975 m.). Sudarè A. Viršulis. Vilnius: Mintis, 1975.

Jakštas, Arvydas. „Faleristikos kolekcijos Lietuvos sporto muziejuje (1918-1940)“. In Lietuvos muzieju rinkiniai, XI mokslinè konferencija Lituanistika muziejuose, 94-96. Vilnius: Lietuvos muziejų asociacija, 2009.

Jakštienè, Asta, Rūta Kuodytè ir Rita Povilovska. „Šiuolaikinių lituanistinių faleristikos eksponatų saugojimo problema“. In Lietuvos muzieju rinkiniai: XI mokslinè konferencija Lituanistika muziejuose, 97-100. Vilnius: Lietuvos muziejų asociacija, 2009.

Jankevičiūtè, Giedrè. Po raudonaja žvaigžde: Lietuvos daile 1940-1941 m. Vilnius: Lietuvos kultūros tyrimų institutas, 2011.

Kaminskas, Petras. Šiauliai faleristikoje 1879-2016. Šiauliai, 2016. 
-. Šiauliai faleristikoje 1924-2020.

Katalogo papildymas. Šiauliai: spaustuvè „Titnagas“, 2020.

Klimas, Audrius. Lietuvos prekiu ženklai: istorija, funkcija, klasifikacija. Vilnius: Vilniaus dailès akademijos leidykla, 2009.

Kšivickas, Algimantas. Jonava faleristikoje. Vilnius: Diemedžio leidykla, 2018.

Kuodytè, Rūta. „Algimanto Astiko kolekcija ir jos reikšmè Lietuvos nacionalinio muziejaus faleristikos ir filofaleristikos rinkinių formavimui“. In Lietuvos muzieju rinkiniai: XIII mokslinè konferencija Lietuvos muziejininkysté: raida ir asmenybès, 93-97. Vilnius: Lietuvos muziejų asociacija, 2010.

Lapinskas, Kęstutis. „Ženklelis“. In Tarybu Lietuvos enciklopedija. T. 4, 668. Vilnius: Vyriausioji enciklopediju redakcija, 1988.

Lietuvos sakralinè dailè, t. 2, Šiauliu vyskupija, d. 2, Šiauliu dekanatas, kn. 1, AgailiaiJuozapava. Sudarè Dalia Vasiliūnienè ir Skirmantė Smilingytè-Žeimienė. Vilnius: Lietuvos kultūros tyrimų institutas, 2018.

Mažvydo klubas: Mažvydo knygos bičiuliu klubo pédsakais. Sudarė Jurgis Stašaitis, Albinas Vaičiūnas ir Birutė Sriogytè-Vaitkienè. Vilnius: Krantai, 2010.

Narbutas, Ignas. „XIX a. pabaigos - XX a. pradžios JAV lietuvių faleristikoje naudojamos heraldikos kilmé". In Šiuolaikiness gairès ir aktualijos numizmatikoje, faleristikoje ir sfragistikoje, 56-58. Trakai: Trakų istorijos muziejus, 2006.

Numizmatika. 17 t. Vilnius: Lietuvos nacionalinis muziejus, 2000-2017.

Poviliūnas, Virgilijus. Lietuvos Respublikos meru regalijos. Trakai: Trakų istorijos muziejus, 2003.

Prekevičius, Vaclovas ir Gediminas-Leonas Samuolis. Dailès dirbiniu ir suvenyru gamyba ir jos išsivystimo Lietuvos TSR vietinèje pramoneje problemos. Vilnius: Lietuvos mokslinès techninès informacijos ir techninès ekonominès analizès mokslinio tyrimo institutas, 1972.

Putinaitè, Nerija. Skambantis molis: Dainu šventès ir Justino Marcinkevičiaus trilogija kaip sovietinio lietuviškumo ramsčiai. Vilnius: Naujasis Židinys-Aidai, 2019.
Remecas, Eduardas. „Katalikiški ženkleliai tarpukario Lietuvoje: jų priklausomybè, datavimas, platinimas ir tiražavimas". Lietuvos kataliku mokslo metraštis 37 (2013): 207-226.

—. Lietuvos numizmatikos bibliografija 1815-1999: bonistika, faleristika, medalininkystè, numizmatika. Vilnius: Lietuvos nacionalinis muziejus, 2001.

—_. „Lietuvos skautų organizacijos ženkleliai 1918-1940 m." Lietuvos kataliku mokslo metraštis 42 (2019): 183-215.

—_. „Lietuvos sukarintų organizacijų ženklai ir ženkleliai (1918-1940): istorija ir datavimas". Karo archyvas 30 (2015): 343-377.

Smilingytė-Žeimienė, Skirmantè. „Šiek tiek apie mažiausius Lietuvos istorijos paminklus“. Menotyra 2 (19) (2000): 39-41.

Škiudienè, Rita. „Tam tikri tarpukario auksakalystès bruožai“. In Primityvumas mene, 340-353. Vilnius: Kultūros ir meno institutas, 1999

,Tarpukario Kauno žydų meistru įnašas į Lietuvos auksakalystę“. In Lietuvos žydu kultūros paveldas: kasdienybès pasaulis, 427-558. Vilnius: Lietuvos kultūros tyrimų institutas, 2013.

Teminis meno verslu ir suvenyru katalogas. Vilnius, Mintis: 1971.

Trakai numizmatikoje. Sudarè Virgilijus Poviliūnas, Irena Senulienè ir Oleg Ševeliov. Trakai: Trakų istorijos muziejus, 2013.

Verkelienè, Rūta. „Retesni mažosios faleristikos eksponatai“. In Mažieji Lietuvos istorijos paminklai Nacionalinio M. K. Čiurlionio dailès muziejaus Numizmatikos skyriaus rinkininose, 119-131. Kaunas: Nacionalinis M. K. Čiurlionio dailès muziejus, 1999

Vilniaus kombinatas „Daile““. Vilnius: LTSR Dailès fondo Vilniaus „Dailès“ kombinatas, 1978.

Vilnius ženklelinose. Sudarė Birutė Railienè ir Darius Raila. Vilnius: Lietuvos mokslų akademijos Vrublevskiụ biblioteka, 2005. 


\title{
Summary
}

\section{The Phenomenon of Mass Production of Soviet-Era Souvenir Badges in Lithuania}

\author{
Rasa Dargužaitè
}

Keywords: design, souvenirs, Soviet propaganda, badges.

During the Soviet period, badges for various occasions, celebrations, events, organizations, and propaganda purposes were mass-produced. The mass production of badges became a mass reproduction of images, which penetrated all areas of private life - work, study, and leisure. Research on a wide range of badges sheds light on the celebrations, events and sports competitions that took place during the Soviet period. Signs of this type speaks volumes about the life of Soviet society, having been witnesses to a certain historical period and its events.

The article has two objectives. Firstly, it discusses why mass-produced badges were widespread in Lithuania during the Soviet period, and secondly, it analyzes the design of Soviet badges, which has so far received little research attention, and considers their artistic and aesthetic value. The author briefly addresses the issue of souvenirs in general, which were given special attention during the Soviet period.

As badges were mass products, the majority of their designers are unknown. Referring to the material found in the surviving archives of the Dailè Art Production Factory, workshops the Metalistas, Minija, and Üla companies, and the technical data sheets of the products, the author of the article managed to identify a number of masters and designers of badge projects, among them famous Lithuanian jewellers, designers and painters Feliksas Daukantas, Kazimieras Simanonis, Birutė Stulgaitè, Marytė Gurevičienè and others. It appears that the mass phenomenon of badge production and circulation is inseparable from the social factors and the political situation. In the period of Soviet occupation, badges were one of many ways

$103-2021$

Acta Academiae Artium Vilnensis 
to implement ideology in Lithuania - to spread and validate propaganda through images and symbols, penetrating all areas and activities of human life. However, it was not in all badges that Soviet agitation and propaganda content was obvious. The case of badges is interesting and noteworthy as badges can illustrate Soviet design trends as well as serve as a reflection of social life of that time. 